\title{
A novel fragmented anode biofilm microbial fuel cell (FAB-MFC) integrated system for domestic wastewater treatment and bioelectricity generation
}

Tesfalem Atnafu ${ }^{1,2^{*}}$ and Seyoum Leta ${ }^{1}$

\begin{abstract}
Background: The critical MFC design challenge is to increase anode surface area. A novel FAB-MFC integrated system was developed and evaluated for domestic wastewater treatment. It was operated in fed-batch flow mode at $1-3$ days of HRT with $755 \mathrm{mg} / \mathrm{LCOD}_{\mathbb{N}}$ and $0.76 \mathrm{~kg}-\mathrm{COD} / \mathrm{m}^{3} /$ day. The study includes anaerobic-MFC and aerobic-MFC integrated systems. Microbial electrode jacket dish (MEJ-dish) with hybrid dimension (HD) was invented, first time to authors' knowledge, to boost anode biofilm growth. The treatment system with MEJ+ (FAB) and MEJ- (MFC) anode are called FAB-MFC and MFC, respectively.
\end{abstract}

Results: Fragmented variable anode biofilm thickness was observed in FAB than MFC. The FAB-MFC (FAB+) simple technique increases the anode biofilm thickness by 5 times MFC. Due to HD the anode biofilm was fragmented in FAB + system than MFC. At the end of each treatment cycle, voltage drops. All FAB+ integrated systems reduced voltage drop relative to MFC. FAB reduces voltage drops better than MFC in anaerobic-MFC from 6 to $20 \mathrm{mV}$ and aerobic-MFC from 35-47 mV at $1 \mathrm{k} \Omega$ external load. The highest power density was achieved by FAB in anaerobic-MFC $\left(F A B=104 \mathrm{~mW} / \mathrm{m}^{2}, M F C=98 \mathrm{~mW} / \mathrm{m}^{2}\right)$ and aerobic-MFC integrated system $\left(F A B=59 \mathrm{~mW} / \mathrm{m}^{2}, M F C=42 \mathrm{~mW} / \mathrm{m}^{2}\right)$.

Conclusions: The $\triangle C O D$ and CE between FAB and MFC could not be concluded because both setups were inserted in the same reactor. The integrated system COD removal (78-97\%) was higher than the solitary MFC treatment (68-78\%). This study findings support the FAB + integrated system could be applied for real applications and improve performance. However, it might depend on influent COD, the microbial nature, and $\triangle \mathrm{COD}$ in FAB+ and MFC, which requires further study.

Keywords: Microbial fuel cell, Fragmented anode biofilm reactor (FAB), Electroactive biofilm (EAB), Anode surface area, Microbial electrode jacket dish (MEJ-dish)

\section{Introduction}

The modern wastewater treatment (WWT) system is expected to be energy-autonomous and zero liquid discharge (Li et al. 2013; Stoll et al. 2018). In conventional activated sludge WWT, sludge management accounts for

\footnotetext{
*Correspondence: tesfalem_atnafu@yahoo.com

${ }^{1}$ Center for Environmental Science, Addis Ababa University, Addis Ababa, Ethiopia

Full list of author information is available at the end of the article
}

$30-50 \%$ of operating costs and the remaining $50 \%$ for aeration (Abbassi et al. 2020; Stoll et al. 2018). The aeration demands $0.5-0.29 \mathrm{kWh} / \mathrm{m}^{3}$ (3-5\% of developed countries national energy budget), which costs $\$ 0.12 / \mathrm{m}^{3}$ (per annum $\$ 7.5$ and $\$ 0.51$ billion in the United States and South Korea, in turn) (Li et al. 2013; Yu et al. 2012), and 0.13-0.14 $\mathrm{tCO}_{2} / \mathrm{m}^{3}$ released (Goto and Yoshida 2019). During treatment, per $1 \mathrm{~kg}$ COD removal, $\sim 1 \mathrm{kWh}$ consumed (Ahn and Logan 2010) and $0.4 \mathrm{~kg}$ (40\% of removal) converted to dry solid sludge ( $\mathrm{Ng}$ et al. 2006). The sludge 
contains high (66\%) organic matter that requires additional treatment (He et al. 2017). Meanwhile, the wastewater is endowed with organic matter that can generate 9.3 times the energy required for treatment (Logan and Regan 2006), equivalent to $4.9-7.9 \mathrm{kWh} / \mathrm{kg}$ COD or $7.6 \mathrm{~kJ} / \mathrm{L}$ that vary based on source (Heidrich et al. 2011). Hence, developing a WWT system that reduces pillar challenges, sludge and aeration, sound sustainable.

Microbial fuel cell (MFC) is a promising sustainable technology with multiple applications such as renewable energy source, WWT, biosensors, and bio-hydrogen production (He et al. 2017). MFCs reduce sludge by $6-11 \%$ (Gajaraj and $\mathrm{Hu} 2014$ ) and 65-71\% (Brown et al. 2015) than membrane bioreactor (MBR) and activated sludge treatment, respectively. It is aeration-free treatment technology with a low carbon footprint that generates energy $\left(1.43 \mathrm{kWh} / \mathrm{m}^{3}\right)$ and income $(\$ 15 / \mathrm{kW})$ (MunozCupa et al. 2021). A typical MFC consists of microorganisms, the substrate as a fuel, electrodes (anode and cathode) separated with a proton exchange membrane (PEM). MFC operated either with mixed culture or monoculture (Geobacter, Shewanella sp.) (Logan 2008). These microbes are known as exoelectrogen, oxidizing organic matter and directly transfer the electron to the electrode or with mediators (Nosek et al. 2020). Hence, electrodes are MFC central focuses that attract a critical concern for realizing the practicality (Wei et al. 2011).

However, MFC is currently facing several technical and practical issues for scale-up and commercialization. Several articles were published on the MFC advantages, limitations, and future outlooks (Choudhury et al. 2017; He et al. 2017; Li et al. 2013; Logan and Regan 2006; Santoro et al. 2017; Xu et al. 2016). These authors noted the MFC challenges are related to electrode design, high operating cost, PEM, reactor configuration, and a lack of clear understanding of the electro-biochemical activity. Lessons learned from past studies show that MFC efficiency depends on thick anode biofilm growth and development (Liu et al. 2004; Logan 2008; Logan and Regan 2006). Most studies focus on reactor configuration and optimization, whereas the future of MFC requires a novel electrode to intensify anode EAB growth (Choudhury et al. 2017). Nosek et al. (2020) emphasize that sustainable MFC should modify the existing anode materials for enhanced bacterial attachment and adhesion. Generally, authors who studied anode modification agree that power production increases with increasing anode surface area (Nosek et al. 2020; Zhou et al. 2012). As a result, increasing the bio-electrode surface area becomes the MFC research spotlight.

The core MFC challenge is increasing anode surface area (Lovley 2006). The present means to increase anode surface area were anode modification by nanomaterials, heat, and chemical treatment (Wei et al. 2011). Etching the anode with chemical form groves that increases surface area for microbial attachment (Nosek et al. 2020). For instance, anode treated by ammonium nitrate and nitric acid increased power from the initial $552 \mathrm{~mW} / \mathrm{m}^{2}$ by $33 \%\left(736 \mathrm{~mW} / \mathrm{m}^{2}\right)$ and $43 \%\left(792 \mathrm{~mW} / \mathrm{m}^{2}\right)$, respectively (Zhou et al. 2012). Previously different anode geometries were studied, such as reticulate vitreous carbon, granular activated carbon, carbon foam, graphite brush electrodes, 3D, graphite pellets, carbon felt, and from flat sheet to packed bed (Yu et al. 2017; Zhou et al. 2012). Up to date, the research gaps on anode modifications were electron loss due to current and mass distribution (Di Lorenzo et al. 2010), complex to prepare or scale-up (Sayed et al. 2020; Xu et al. 2016), expensive (Zhu et al. 2011), and not flexible to manage the biofilm thickness.

The advent of nanotechnology and change from 2D to $3 \mathrm{D}$ (three-dimension) electrode results in $3 \mathrm{D} \mathrm{EAB}$ formation, and it is expected to step MFC forward (Yu et al. 2017). Self-assembled hybrid biofilms (SAHB) can develop a centimeters thick biofilm, a $100 \times$ natural biofilm on a planar 2D surface. Nakamura et al. (2009) added $\alpha-\mathrm{Fe}_{2} \mathrm{O}_{3}$ into Shewanella, a light-induced $\alpha-\mathrm{Fe}_{2} \mathrm{O}_{3} /$ bacteria hybrid network, and increased electroactivity $300 \times$ MFC. Chen et al. (2015) developed a porous carbon electrode with a defined pore size $(400 \mathrm{~nm})$ by etching $\mathrm{SiO}_{2}$ template with sucrose and $\mathrm{H}_{2} \mathrm{SO}_{4}$ in $10 \% \mathrm{HF}$ and improved power density to $1.6 \mathrm{~W} / \mathrm{m}^{2}, \sim 4 \times$ carbon felt. The limitation of nanomaterial self-assembly on a 2D electrode was a narrow pore size could not facilitate biofilm growth that requires no $<100 \mu \mathrm{m}$ (Yu et al. 2017). Also, the fixed pore size hinders the flexible adjustment of the biofilm thickness. It might not be easy to regenerate the electrode (nanosized pore) via simple cleanup (rinsing) for long-term operation. Carbon cloth electroplated with iron nanostructure produces a power output of $80 \mathrm{~mW} / \mathrm{m}^{2}$, more than $2 \times$ bare MFC (Sayed et al. 2020). Still, the long-term 3D electrode (carbon foam) operation is difficult due to anode fouling (Ahn and Logan 2010). In summary, a simple technique to modify anode surface area with flexible mechanisms to increase $E A B$ growth, easily manage the biofilm, and regenerate the electrode is required.

Another best approach to mitigate these problems was integrating MFC with other WWT processes to improve the performance (Xu et al. 2016). The integrated systems enhance pollutant removal efficiency and electricity generation (Abbassi et al. 2020). Previous studies on aerobic or anaerobic pretreatment for MFC-integrated system show reduced energy requirement and the discharge effluent's COD load (Goto and Yoshida 2019). Wang et al. (2012) developed a novel MBBR-MFC and achieved a higher power density of $6.0 \mathrm{~W} / \mathrm{m}^{3}$ with an 
average current of $1.9 \pm 0.4 \mathrm{~mA}$. Despite intensive works to improve the MFC-integrated WWT system, there are still crucial research gaps (Chen et al. 2019). These drawbacks were lower electricity generation, controlling the substrate or DO shock, electrode surface area, terminal $\mathrm{e}^{-}$acceptor at the cathode, reactor configuration, voltage drop, and increased internal resistance (Abbassi et al. 2020). Hence, integrating MFC with other WWT systems is not simply connecting and increasing the reactor number and size (Logan 2008); instead, these challenges require a novel approach (Abbassi et al. 2020; Li et al. 2013; Oh and Logan 2007). The substrate shock usually results in voltage drop or unequal electrode potential that lowers electricity generation or the system's failure (He et al. 2017). Developing a technique to control voltage drop is a fundamental concern for the long-term MFCs operation (Oh and Logan 2007). The future advanced MFCs focus on the MFC-integrated WWT system to increase energy generation through minimizing the internal resistance, increasing $\mathrm{EAB}$ thickness through novel design, and MFCs configuration (Abbassi et al. 2020).

To the best of the authors' knowledge, for the first time, a fragmented anode biofilm (FAB) approach to support variable anode biofilm thickness formation with a flexible controlling technique using MEJ-dish (flexible hybrid 3D electrode) was introduced in this study. It is flexible because when the MEJ-dish is removed easily transforms 3D into a 2D electrode. The MEJ+ is a hybrid dimension (HD) electrode: it comprises 2D and 3D in a single design (Additional file 1: Fig. S8), due to the HD biofilms fragment across the electrode. The study hypothesizes that biofilm growth varies on the $2 \mathrm{D}(\mathrm{MEJ}-=$ thin) and $3 \mathrm{D}$ $(\mathrm{MEJ}+=$ thick) surfaces. The study objectives were to (i) employ comparative research on the anaerobic-MFC and aerobic-MFC integrated system with a novel FAB technique; (ii) examine the effect of increased anode surface area on anode biofilm and voltage drop using domestic wastewater. The performance was evaluated in terms of bioelectrochemical output and COD removal efficiency.

\section{Materials and methods Experimental setup}

Figure 1 shows the bench-scale anaerobic-MFC and aerobic-MFC integrated system experimental setup. It consists of screening, sedimentation, anaerobic, aerobic, methanogenic, and MFC reactor. The aerobic reactor was designed as a moving bed biofilm reactor (MBBR) with a K3 filter $(\varnothing 25 \mathrm{~mm} \times 10 \mathrm{~mm})$ media carrier $(\mathrm{Cz}$ Garden Supply, USA); detailed design is shown in Additional file 1: Figs. S3-S4. The reactors were constructed from polypropylene containers, each having a total working volume of $4 \mathrm{~L}(\varnothing 18 \mathrm{~cm} \times 20 \mathrm{~cm}$ in height). The

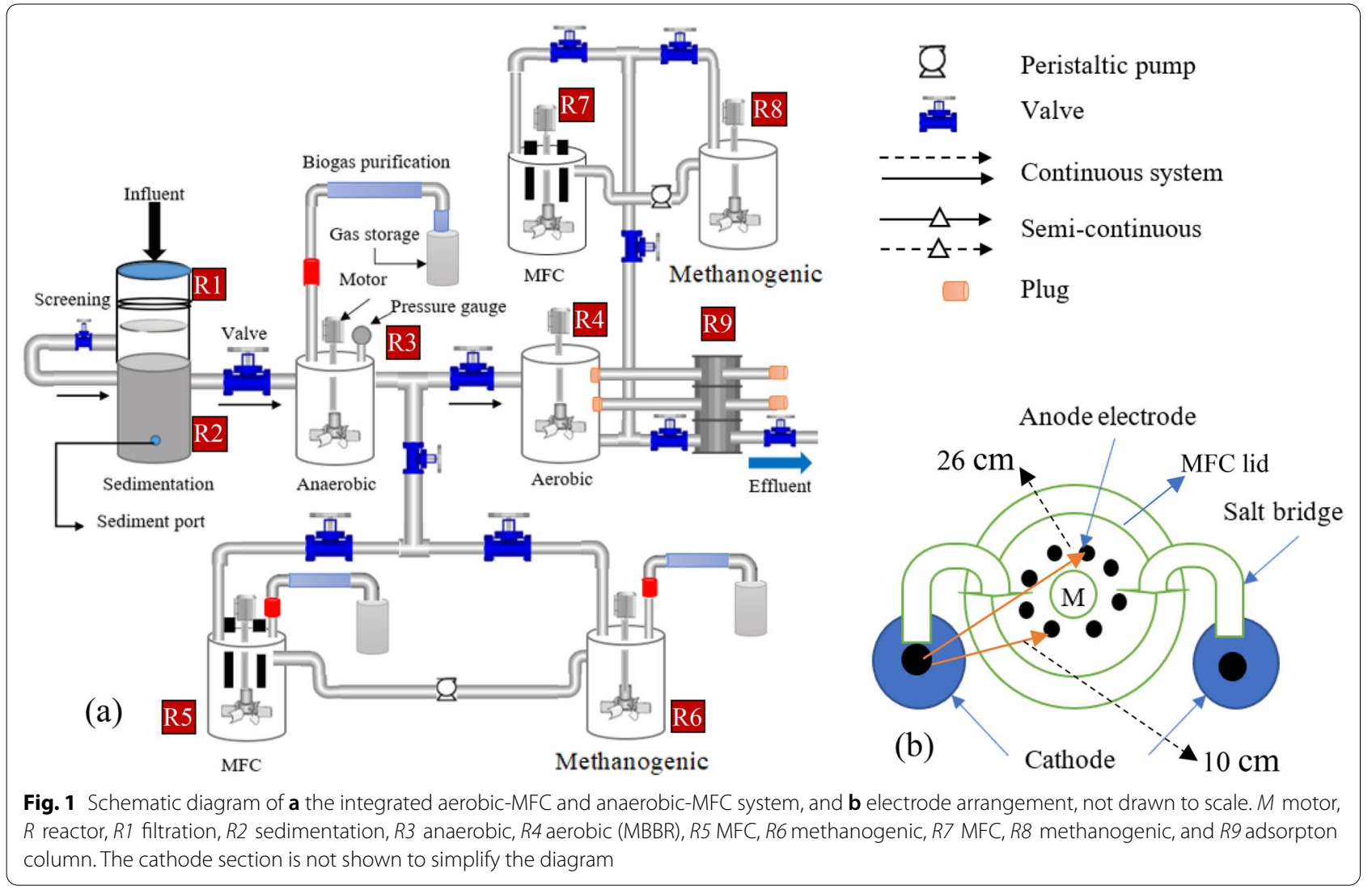


methanogenic and cathode reactors were made from a glass bottle (Ø12 cm and $23 \mathrm{~cm}$ high) and a Schott Duran bottle with a working volume of 4 and $1 \mathrm{~L}$, in turn.

The MFCs were double chambered. In the anode chamber, the electrode with microbial electrode jacket dish (MEJ-dish) was considered as FAB (MEJ+), and without MEJ-dish (MEJ-) was labeled as MFC. The MFC treatment system of MEJ+and MEJ- are called FAB-MFC $(\mathrm{FAB}+)$ and MFC, in turn. In this study, both MEJ+ and MEJ- electrodes were inserted into the same MFC anode chamber (Fig. 2). Four MEJ dishes were inserted per electrode (Fig. 3). The MEJ dishes were made from K3 filter media, drilled at the center. The anode reactor consists of eight graphite rods (4 MEJ+, 4MEJ-) arranged concentrically (Fig. 1b), and each anode $2 \mathrm{~cm}$ space-separated; this distance was reported to reduce internal resistance (Logan 2008). The electrodes were placed in a sequence (i.e., if first MEJ+ then MEJ-) to minimize the effect of near anodic $\mathrm{pH}$ and fuel homogeneity variation.

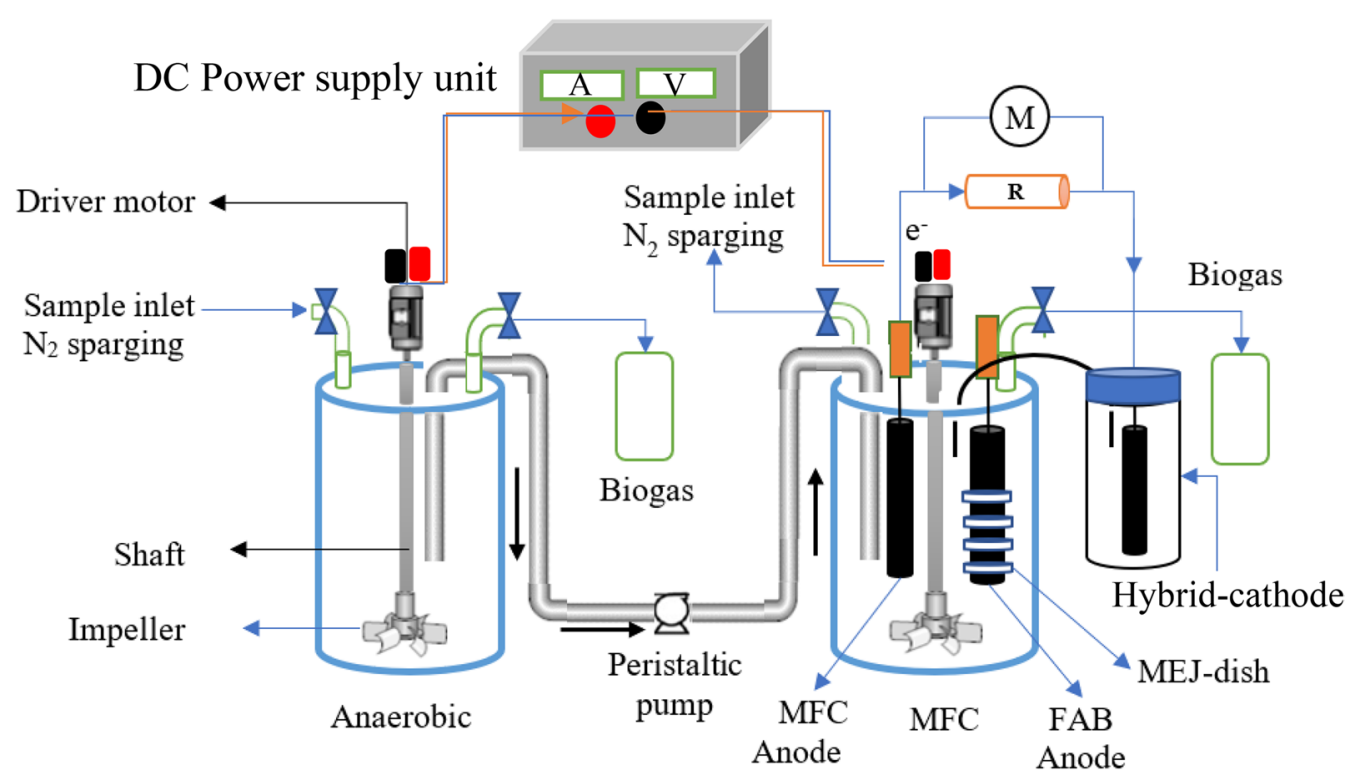

Fig. 2 The schematic diagram for a semi-continuous anaerobic-microbial fuel cell (anaerobic-MFC) integrated treatment system. The second air-cathode chamber was not shown to simplify the diagram. M a multimeter, FAB fragmented anode biofilm, MEJ-dish a microbial electrode jacket dish. Arrows indicate the wastewater flow path

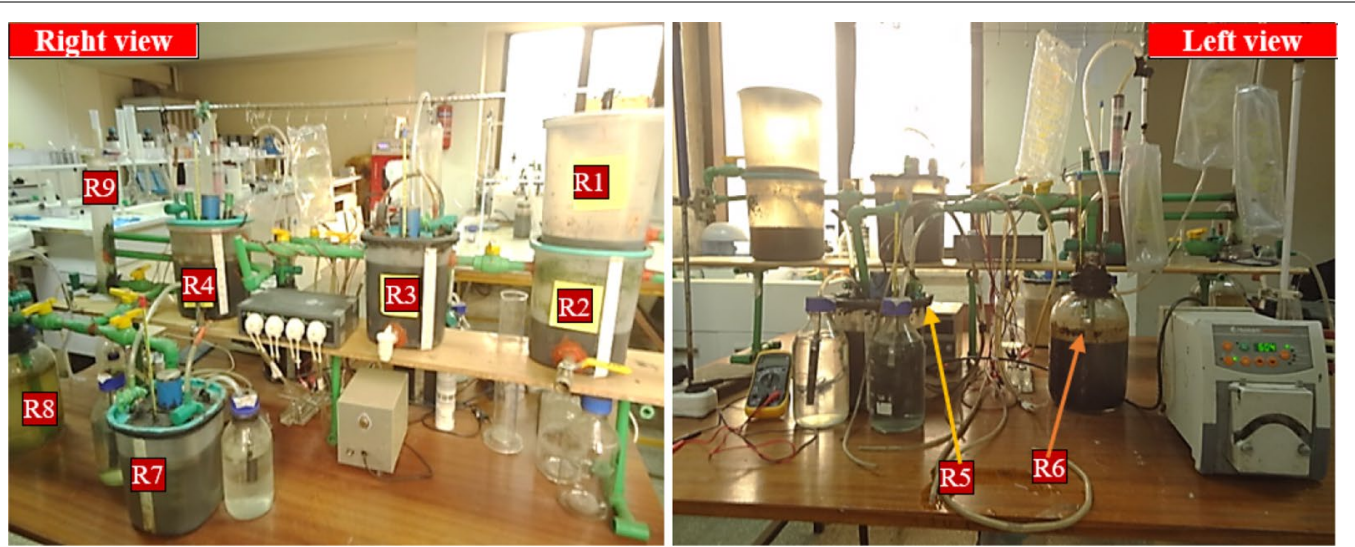

Fig. 3 Photo of the constructed MFC-integrated wastewater treatment system, right and left side view. R1-9 indicates the reactor number (for details, see Fig. 1) 
Two separate hybrid-cathode chambers were placed opposite and an anode in the middle (Fig. 1b). The nearest distance from the hybrid-cathode to the anode was $10 \mathrm{~cm}$, whereas $26 \mathrm{~cm}$ (to another anode edge). A hybridcathode was made from a single graphite rod $(3.5 \mathrm{~cm}$ exposed to air and $9 \mathrm{~cm}$ immersed in the tap water). The hybrid-cathode was used to avoid the aeration demand; hence, all cathode chambers were not aerated throughout the study period. Each anode is connected to the cathode with an individual circuit. The MEJ+ and MEJ- anodes were connected to a separate cathode chamber with a similar graphite rod. All electrodes were placed perpendicular to the bottom of the reactor (Fig. 2). The MFC electrode arrangement and reactor configuration were similar regardless of the integration mechanism.

Each graphite rod's total surface area was $40.8 \mathrm{~cm}^{2}$ (Ø1 cm $\times 12.5 \mathrm{~cm}$ in height) without including the pores formed during abrasion with sandpaper. A single K3 MEJ-dish (deduct anode diameter, $\varnothing 15 \mathrm{~mm} \times 10 \mathrm{~mm}$ ) provides an additional $1.8 \mathrm{~cm}^{2}$. A total of $4 \mathrm{MEJ}$-dishes increased the top surface area by $7 \mathrm{~cm}^{2}$ to support microbial attachment on the anode surface. Hence, assuming the MEJ-dish was conductor, and the junction cover between the anode and MEJ-dish was negligible, it increased the anode's total surface area by $33 \mathrm{~cm}^{2}(81 \%)$.

\section{Operation}

Anaerobic-MFC and aerobic-MFC integrated system operation is shown in Fig. 4a, b. A similar flow pattern was followed among the aerobic or anaerobic-MFC integrated systems. The study was divided into three phases: the first phase (MFC-1), the influent was directly fed into the MFC. In the second phase (MFC-2), hydrolysis (anaerobic) effluent was fed to FAB-MFC. In the third phase (MFC-3), the anaerobic effluent was fed to the methanogenic reactor then transferred to FAB-MFC. The reactors were operated in fed-batch mode with four stages in 24:1 h sedimentation- $R 2$, 30-min fill, $21 \mathrm{~h}$ react (6 h mix), $1 \mathrm{~h}$ settle, and 30-min decant. Equal $4 \mathrm{~L} /$ day WW were decanted and filled. The integrated systems were compared under different pretreatment with similar 1 day of HRT in MFC at $0.76 \mathrm{~kg}-\mathrm{COD} / \mathrm{m}^{3} /$ day. The HRTs were 1,2 , and 3 days in MFC-1, -2 , and -3 , respectively.

The wastewater fill and decant were conducted using a programmable auto-dosing pump (DP-4, Jebao Co., Ltd., China) to minimize the effect of MFC oxygen contamination. An aquarium air pump (SB-9903/A, SOBO ${ }^{\circledR}$, China) with a capacity of $5 \mathrm{~L} / \mathrm{min}$ was used to supply compressed air into the aerobic MBBR reactor intermittently. The liquid contents were mixed using an overhead mounted motor to keep even biomass distribution. Each integrated system was operated for more than 30 days before evaluating the performance. The reactors were inoculated with mixed culture and operated at room temperature ( $25 \pm 1$ $\left.{ }^{\circ} \mathrm{C}\right)$ without sludge returning, $\mathrm{pH}$ adjustment, or nutrient addition. All the systems were considered steady-state when voltage output was less than $0.01 \mathrm{~V} / \mathrm{h}$ variation under $1000 \Omega$ external load.

\section{Wastewater sampling and characterization}

Wastewater (WW) sampling and analysis were conducted according to APHA (2005). Influent WW used for this study was collected from a primary clarifier of Mickey Leland condominium domestic WWT plant

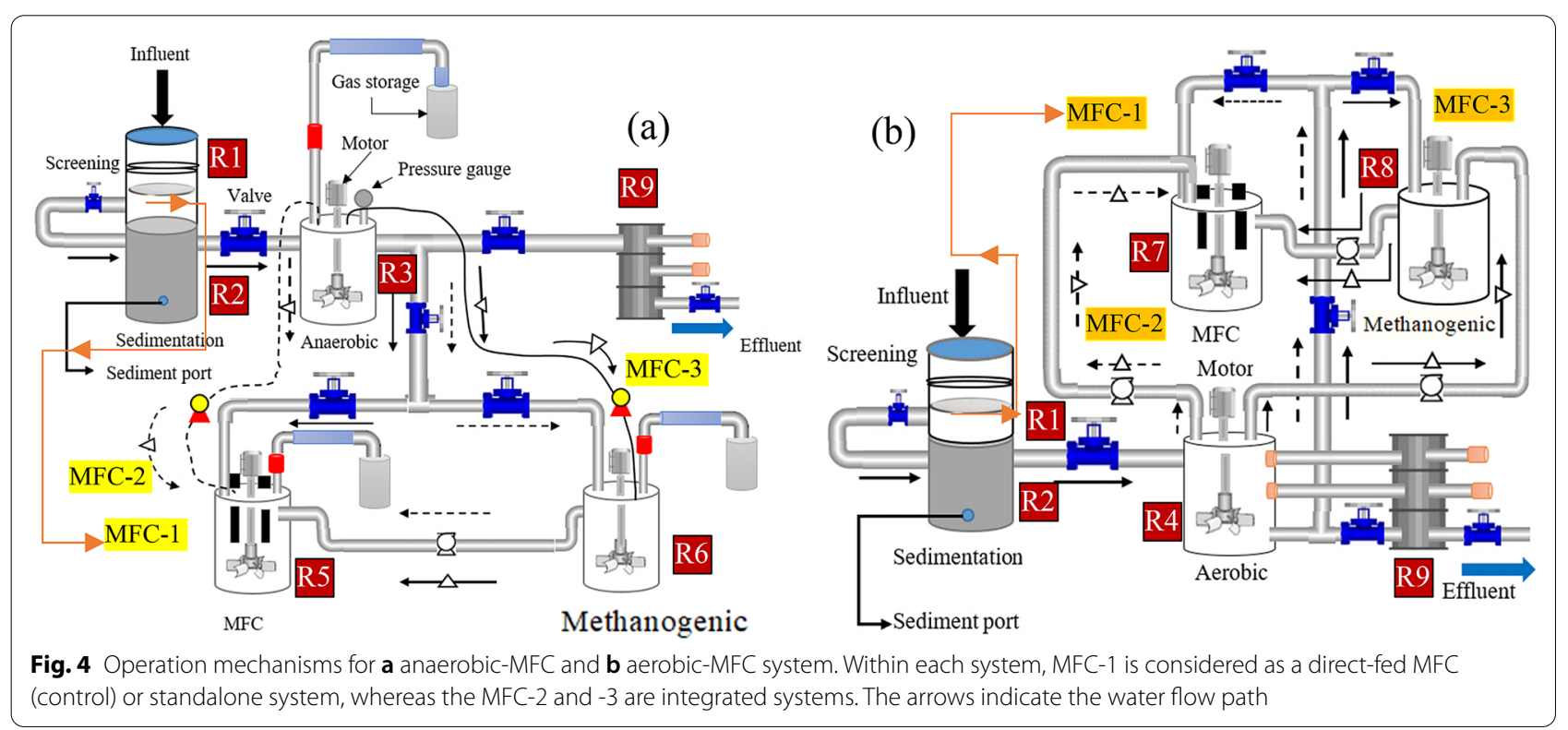


(Asko, AA, Ethiopia). WW was collected every 3 days to expose the designed treatment system to actual COD fluctuation in the primary clarifier. The collected samples were either used immediately upon arrival to the laboratory or stored at $4{ }^{\circ} \mathrm{C}$ in a refrigerator. Influent and treated water samples were taken per specified HRT and analyzed for COD concentration. The raw WW, inoculant, and inoculum were analyzed for volatile solids, total solids, total alkalinity, ammoniacal nitrogen $\left(\mathrm{NH}_{4}^{+}-\mathrm{N}\right)$, and total phosphorus. The temperature was measured using the reactor top-mounted thermometer, while $\mathrm{DO}$ and $\mathrm{pH}$ were measured using a probe. All physicochemical and bioelectrochemical analyses were conducted at least in duplicate. Table 1 summarizes the raw wastewater, inoculum, and inoculant physicochemical characteristics.

\section{Anode biofilm sampling and characterization}

Millo (2015) and Bakke et al. (2001) optical methods were adopted with modification to measure the anode biofilm thickness (BT). The anode electrodes were scrapped using a scalpel until the graphite electrode surface was observed, the biofilm tip was fixed facing the optical microscope objective. The biofilms were dispersed on the electrode surface; at least five $n$ independent biofilms $(5 \leq n \leq 10)$ per $1 \mathrm{~cm}$ of anode projected area $\left(4.71 \mathrm{~cm}^{2}\right)$ were measured. It was difficult to quantify all BT at different biofilm growth stages, from prokaryotic cells to matured biofilms. Hence, the top BT at the specified $n$ range was reported, excluding outliers or infrequently observed BT (did not occur at least five times per $\mathrm{cm}$ of electrode). The method was validated using a standard, Kapton ${ }^{\circledR}$ tape (DuPont Co., USA) with a manufacturer-reported thickness of $88.9 \mu \mathrm{m}$, including the glue part. A tape was wrapped around a bare electrode without overlapping. The measurement of the tape thickness was carried out as described above. The test was run in triplicate

Table 1 Characteristics of raw, inoculum, and influent wastewater (mean \pm SD)

\begin{tabular}{lccc}
\hline Parameters & Raw wastewater & Inoculant & Inoculum \\
\hline $\mathrm{pH}(-)$ & $7.51 \pm 0.07$ & $6.43 \pm 0.06$ & $6.97 \pm 0.03$ \\
Total alkalinity (mg/L as & $35 \pm 21$ & $144 \pm 15$ & $130 \pm 42$ \\
$\left.\mathrm{CaCO}_{3}\right)$ & & & \\
Total solid (mg/L) & $158 \pm 29$ & $3277 \pm 416$ & $2894 \pm 83$ \\
Volatile solid (mg/L) & $366 \pm 59$ & $1559 \pm 211$ & $1347 \pm 60$ \\
Total COD (mg/L) & $755 \pm 160$ & $9760 \pm 551$ & $5782 \pm 50$ \\
Ammonia-N (mg/L) & $35 \pm 9$ & $272 \pm 41$ & $168 \pm 21$ \\
Total phosphorus (mg/L) & $9 \pm 3$ & $31 \pm 11$ & $17 \pm 5$ \\
\hline
\end{tabular}

$(n=5)$, and BT measurement accuracy was about $95 \%$ $(84 \pm 1.4 \mu \mathrm{m})$ with $\pm 6 \mu \mathrm{m}$ precision $(93 \%)$.

\section{Electrochemical analysis}

The anode and cathode were connected across 1000 $\Omega$ external resistance $\left(R_{\text {ext }}\right)$ unless otherwise stated. The voltage was measured using a digital multimeter (XL830L, China). Data were recorded at least three times per day, and the daily average was presented. The current (I) was calculated based on Ohm's law as $I=V / R_{\text {ext }}$ and power output $(P)=I V\left(V^{2} / R_{\text {ext }}\right)$, where $I$ is the current (A), $V$ is the voltage $(\mathrm{V})$, and $R_{\text {ext }}$ is the external resistance $(\Omega)$. Power density $\left(\mathrm{mW} / \mathrm{m}^{2}\right)=P / A$, and current density $\left(\mathrm{mA} / \mathrm{m}^{2}\right)=I / A$, where $A$ is normalized to the submerged cathode area $\left(A=29.83 \mathrm{~cm}^{2}\right)$ due to variation in anode chamber (MEJ+ or MEJ-), and others as described previously.

\section{Calculations}

The COD removal efficiency and HRT were calculated using Eqs. (1) and (2), respectively.

$$
\mathrm{COD}_{\mathrm{RE}}=\left(1-\frac{\mathrm{COD}_{\mathrm{EF}}}{\mathrm{COD}_{\mathrm{IN}}}\right) \times 100 \%
$$

where $\mathrm{COD}_{\mathrm{RE}}$ is the COD removal efficiency (\%), $\mathrm{COD}_{\mathrm{IN}}$ is an influent COD concentration $(\mathrm{mg} / \mathrm{L})$, and $\mathrm{COD}_{\mathrm{EF}}$ is an effluent COD concentration $(\mathrm{mg} / \mathrm{L})$.

$$
\mathrm{HRT}=\frac{V_{\text {reactor }}}{Q},
$$

where $V$ is the volume of the reactor $\left(\mathrm{m}^{3}\right)$, and $Q$ is the influent flow rate within a specified time ( $\mathrm{m}^{3} /$ day).

Coulombic efficiency (CE) is the ratio of total charge obtained practically $\left(C_{\mathrm{P}}\right)$ to the theoretical value $\left(C_{\mathrm{T}}\right)$ obtained from complete substrate oxidization. CE was calculated based on Eq. (3) (Wen et al. 2009):

$$
\begin{aligned}
\mathrm{CE} & =\frac{C_{\mathrm{P}}}{C_{\mathrm{T}}} \times 100 \%=\frac{8 \int_{0}^{\mathrm{t}_{\mathrm{b}}} I \mathrm{~d} t}{\mathrm{FV}_{\mathrm{an}} \Delta \mathrm{COD}} \times 100 \% \\
& =\frac{8 \mathrm{It}}{\mathrm{FV}_{\mathrm{an}} \Delta \mathrm{COD}} \times 100 \%,
\end{aligned}
$$

where $F$ is Faraday's constant $(96,485 \mathrm{C} / \mathrm{mol}), \triangle \mathrm{COD}$ is the difference between the influent and effluent COD $(\mathrm{mg} / \mathrm{L})$ over a time $\left(t_{\mathrm{b}}\right), I$ is the current $(\mathrm{A})$, and $V_{\text {an }}$ is the liquid volume in the anode $(\mathrm{L})$.

\section{Data analysis}

The collected data were analyzed using IBM SPSS Statistics for Windows, version 20 (IBM Corp., NY, USA). Oneway analysis of variance (ANOVA) was used to compare 


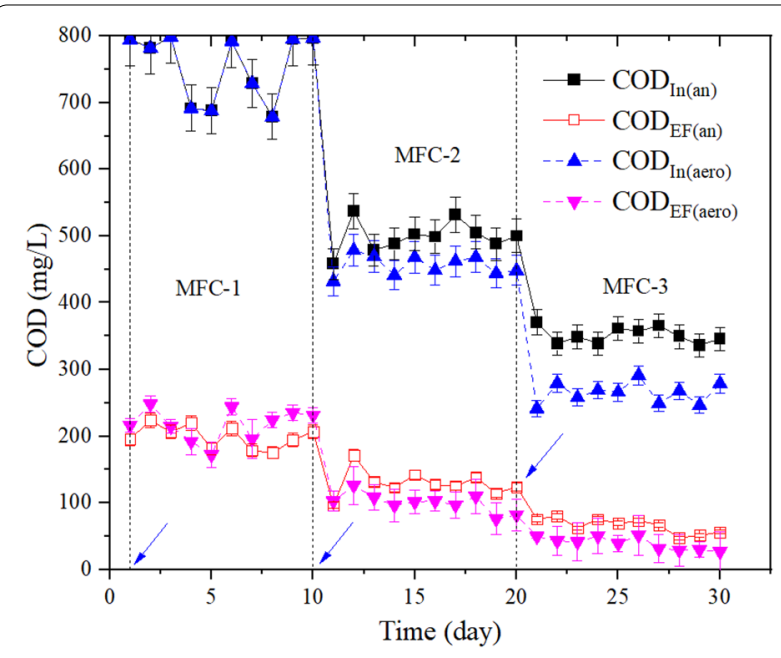

Fig. 5 COD concentration in the influent $\left(C O D_{\mathbb{N}}\right)$ and effluent $\left(\mathrm{COD}_{\mathrm{EF}}\right)$ for aerobic-MFC and anaerobic-MFC integrated system. (an) indicates anaerobic-MFC, and (aero) shows an aerobic-MFC integrated system. The arrows show treatment phase change: wastewater replacement and the systems were allowed to stabilize again. The pre-stabilization period was not shown in the graph. Error bars indicate standard deviation

the MFC bioelectricity or treatment system performance, and $p<0.05$ was considered a significant variation.

\section{Results and discussion}

\section{Performance of anaerobic-MFC}

The anaerobic-MFC integrated treatment system COD concentration in the influent $\left(\mathrm{COD}_{\mathrm{IN}}\right)$ and effluent $\left(\mathrm{COD}_{\mathrm{EF}}\right)$ is shown in Fig. 5. The MFC-1, -2, and $-3 \mathrm{COD}_{\mathrm{IN}}$ were on average 755,496 , and $351 \mathrm{mg} / \mathrm{L}$, respectively. The anaerobic-MFC integrated $\mathrm{COD}_{\mathrm{IN}}$ $(\mathrm{SD}=52 \mathrm{mg} / \mathrm{L})$ was relatively more stable than directly fed MFC $(\mathrm{SD}=23 \mathrm{mg} / \mathrm{L})$. The $\mathrm{COD}_{\mathrm{EF}}$ decreases as the treatment steps increases, MFC-1 $>-2>-3$. Despite $\mathrm{COD}_{\mathrm{IN}}$ fluctuations, the $\mathrm{COD}_{\mathrm{EF}}$ stabilized as the treatment period was extended in all the treatment setups. This result suggests that the $\mathrm{COD}_{\mathrm{EF}}$ was more affected by the operation period than the observed $\mathrm{COD}_{\mathrm{IN}}$ variation. This stability might be associated with the microbial establishment as the operation period (reactor age) increases within 1 day of HRT.

In standalone MFC, the COD removal efficiency $\left(\mathrm{COD}_{\mathrm{RE}}\right)$ was in the range of $72-78 \%$, whereas $78-94 \%$ in the anaerobic-MFC integrated system at a steady state (Fig. 6). There was a significant $\mathrm{COD}_{\mathrm{RE}}$ difference between the standalone MFC and anaerobic-MFC integrated systems. In the MFC, the $\mathrm{COD}_{\mathrm{IN}}$ is not solely used for electricity generation, but also consumed by non-EAB, sediment in the sludge, cell growth, untapped during treatment, and remain effluent (Liu et al. 2004).



Fig. 6 Effects of $\mathbf{a}$ anaerobic-MFC and $\mathbf{b}$ aerobic-MFC integrated system on the FAB-MFC performance in terms of COD removal efficiency $\left(C O D_{R E}\right)$ and coulombic efficiency. $F A B-M F C_{C E}$ and $M F C_{C E}$ show FAB-MFC and MFC coulombic efficiency, respectively. The arrows indicate treatment phase change: previous phase contents emptied, and the system allowed to re-stabilize

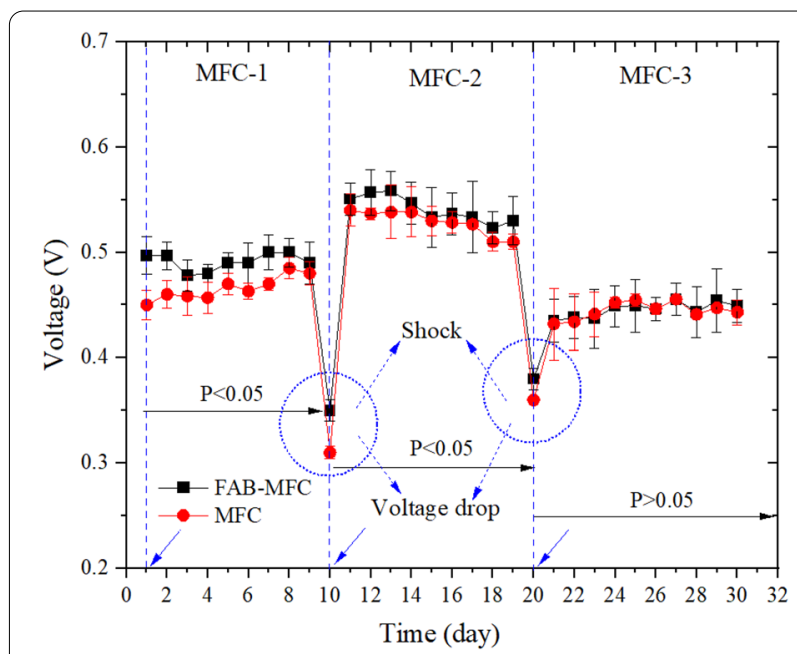

Fig. 7 The voltage generated in the lab-scale anaerobic-MFC integrated domestic wastewater treatment system. Error bars indicate the standard deviation. The $p$ values indicate the significant difference $(p<0.05)$ between the FAB-MFC $(F A B+)$ and MFC. External load 1000 $\Omega$. Shock means the point where the minimum voltage was observed during the transition to the next treatment phase. A circle with arrows indicates wastewater replacement and system shock

Even the COD might be used to generate electron $\left(\mathrm{e}^{-}\right)$ but lost due to bioelectrochemical limitations.

In the anaerobic-MFC integrated system, the mean voltage generated from the higher to lower was MFC-2 $>-1>-3$ (Fig. 7). The figure shows that the highest voltage in MFC-2 was 0.56 (FAB) and $0.54 \mathrm{~V}$ (MFC), which was $0.11-0.13 \mathrm{~V}$ higher than the lowest values observed in MFC-3. Likewise, in MFC-2, the maximum 
power density (MPD) of $104 \mathrm{~mW} / \mathrm{m}^{2}$ (FAB) and $98 \mathrm{~mW} /$ $\mathrm{m}^{2}$ (MFC) were observed at the highest current density of $187 \mathrm{~mA} / \mathrm{m}^{2}$ (FAB) and $181 \mathrm{~mA} / \mathrm{m}^{2}$ (MFC), which was lower than $264 \mathrm{~mW} / \mathrm{m}^{2}$ (Wen et al. 2009), and higher than $37 \mathrm{~mW} / \mathrm{m}^{2}$ (Zhu et al. 2011) and $96 \mathrm{~mW} / \mathrm{m}^{2}$ (Chen et al. 2019). The MPD of the MFC- 1 and -3 were 84 and $70 \mathrm{~mW} / \mathrm{m}^{2}$ for $\mathrm{FAB}, 79$ and $70 \mathrm{~mW} / \mathrm{m}^{2}$ for MFC, respectively (Table 2).
During the transition from MFC-1 to -2 (or -3 ), the contents were emptied and replenished with a fresh substrate to reduce the proceeding system interference. As shown in Fig. 7, a voltage generation drop was recorded in FAB-MFC (FAB+) and MFC $(0.5$ to $0.31 \mathrm{~V})$; this was noted as system shock. However, the FAB+ reduces voltage drop from 6 to $20 \mathrm{mV}$ more than MFC. The voltage drop recorded in this study was within the $0.2 \mathrm{~V}$ range, higher than Gajaraj and $\mathrm{Hu}$ (2014) findings (0.12 V).

Table 2 Comparisons of FAB-MFC integrated system with other studies

\begin{tabular}{|c|c|c|c|c|}
\hline WW type & $\mathrm{COD}_{\mathrm{IN}}\left(\mathrm{COD}_{\mathrm{EF}}\right) \mathrm{COD}_{\mathrm{RE}}$ & MFC type (PEM) HRT & Max.P (I) CE & References \\
\hline \multicolumn{5}{|c|}{ Standalone MFC } \\
\hline Glucose & 1200 (24) 98\% & S-MFC (Nafion) - & $262(-) 55 \%$ & Liu and Logan (2004) \\
\hline Synthetic & 1000 (310) 69\% & S-MFC (Nafion) - & $81(-) 30 \%$ & Di Lorenzo et al. (2010) \\
\hline Swine & 6500 (3400) 49\% & S-MFC (PTFE) 3 days & $0.15(-) 1.0-15 \%$ & Goto and Yoshida (2019) \\
\hline Swine & 7500 (3075) 22\% & S-MFC (No PEM) 0.7 days & 750 (1) $23 \%$ & Kim et al. (2016) \\
\hline Brewery & $627(366) 42 \%$ & S-MFC (Nafion) $2.13 \mathrm{~h}$ & $264(1.79) 20 \%$ & Wen et al. (2009) \\
\hline Domestic & $400(140) 65 \%$ & S-MFC (No PEM) $8.8 \mathrm{~h}$ & $300(-) 36 \%$ & Kim et al. (2015) \\
\hline Domestic & $220(44) 80 \%$ & S-MFC (Nafion) 3-33 h & $26(-) 3-12 \%$ & Liu et al. (2004) \\
\hline Domestic & $-(-)-$ & D-MFC (Salt bridge) - & $0.3(18) 19 \%$ & Min et al. (2005) \\
\hline Domestic & $375(150) 60 \%$ & D-MFC (Salt bridge) - & 25 (100) $0.25 \%$ & Rodrigo et al. (2007) \\
\hline Domestic & $820(180) 78 \%$ & D-MFC (Nafion) 14 days & $817(0.55) 32 \%$ & Bose et al. (2018) \\
\hline Domestic & $300(135) 55 \%$ & S-MFC (Nafion) $78 \mathrm{~h}$ & $28(85) 28$ & Liu and Logan (2004) \\
\hline Domestic & $108(37) 66 \%$ & SE-MFC (Fabric) $6 \mathrm{~h}$ & 149 (250) 6\% & Yu et al. (2012) \\
\hline Domestic & $500(371) 26 \%$ & S-MFC (No PEM) $0.2 \mathrm{~h}$ & 422 (15) $0.7 \%$ & Ahn and Logan (2010) \\
\hline Domestic & 299 (87) 71\% & S-MFC (No PEM) $2 \mathrm{~h}$ & 103 (420) 18\% & You et al. (2006) \\
\hline Domestic & $600(174) 71 \%$ & D-MFC (CEM) $0.69 \mathrm{~d}$ & $180(-)-$ & Ye et al. (2019) \\
\hline $\begin{array}{l}\text { Domestic } \\
\text { Domestic }\end{array}$ & 755 (200) 74\% & $\begin{array}{l}\text { MFC-1 } 1^{A n} \text { (Salt bridge) } 1 \text { day } \\
\text { FAB- } 1^{\text {An }} \text { (Salt bridge) } 1 \text { day }\end{array}$ & $\begin{array}{l}79(163) 0.73 \% \\
84(168) 0.69 \%\end{array}$ & $\begin{array}{l}\text { This study } \\
\text { This study }\end{array}$ \\
\hline $\begin{array}{l}\text { Domestic } \\
\text { Domestic }\end{array}$ & 755 (218) $71 \%$ & $\begin{array}{l}\text { MFC-1 }{ }^{A} \text { (Salt bridge) } 1 \text { day } \\
\text { FAB-1 }^{\mathrm{A}} \text { (Salt bridge) } 1 \text { day }\end{array}$ & $\begin{array}{l}78(161) 0.80 \% \\
87(171) 0.74 \%\end{array}$ & $\begin{array}{l}\text { This study } \\
\text { This study }\end{array}$ \\
\hline \multicolumn{5}{|c|}{ MFC-integrated system } \\
\hline Brewery & 708 (103) 80\% & IVCW-MFC (No PEM) $2 \mathrm{~d}$ & - (50) 0.39\% & Liu et al. (2019) \\
\hline Synthetic & 1500 (375) 75\% & VCW-MFC (No PEM) $4 \mathrm{~d}$ & $16(70) 0.15 \%$ & Yadav et al. (2012) \\
\hline Pulp & $4500(2970) 66 \%$ & MBBR-MFC (Nafion) 3 days & 96 (185) 0.62\% & Chen et al. (2019) \\
\hline Domestic & 537 (17) 97\% & MBR-MFC (No PEM) 1 day & $-(-) 0.05 \%$ & Gajaraj and Hu (2014) \\
\hline Domestic & $430(7) 92 \%$ & MFC-MBR (No PEM) 5 days & $51(0.2) 5.9 \%$ & Su et al. (2013) \\
\hline Synthetic & 600 (60) 90\% & MBR-MFC (No PEM) $2 \mathrm{~h}$ & $140(0.52) 7 \%$ & (Li et al. 2015) \\
\hline Domestic & $1080(32) 97 \%$ & MFC-MBR (No PEM) $3 \mathrm{~h}$ & $380(2000) 8.5 \%$ & Malaeb et al. (2013) \\
\hline $\begin{array}{l}\text { Domestic } \\
\text { Domestic }\end{array}$ & 755 (129) 83\% & $\begin{array}{l}\text { An-MFC-2 (Salt bridge) } 2 \text { days } \\
\text { An-FAB-2 (Salt bridge) } 2 \text { days }\end{array}$ & $\begin{array}{l}98 \text { (181) } 0.80 \% \\
104 \text { (187) } 0.79 \%\end{array}$ & $\begin{array}{l}\text { This study } \\
\text { This study }\end{array}$ \\
\hline $\begin{array}{l}\text { Domestic } \\
\text { Domestic }\end{array}$ & 755 (66) 91\% & $\begin{array}{l}\text { An-MFC-3 (Salt bridge) } 3 \text { days } \\
\text { An-FAB-3 (Salt bridge) } 3 \text { days }\end{array}$ & $\begin{array}{l}70(153) 0.90 \% \\
70(153) 0.91 \%\end{array}$ & $\begin{array}{l}\text { This study } \\
\text { This study }\end{array}$ \\
\hline $\begin{array}{l}\text { Domestic } \\
\text { Domestic }\end{array}$ & 755 (100) 87\% & $\begin{array}{l}\text { A-MFC-2 (Salt bridge) } 2 \text { days } \\
\text { A-FAB-2 (Salt bridge) } 2 \text { days }\end{array}$ & $\begin{array}{l}42(119) 0.57 \% \\
59(140) 0.47 \%\end{array}$ & $\begin{array}{l}\text { This study } \\
\text { This study }\end{array}$ \\
\hline $\begin{array}{l}\text { Domestic } \\
\text { Domestic }\end{array}$ & 755 (39) 95\% & $\begin{array}{l}\text { A-MFC-3 (Salt bridge) } 3 \text { days } \\
\text { A-FAB-3 (Salt bridge) } 3 \text { days }\end{array}$ & $\begin{array}{l}12(63) 0.50 \% \\
18(78) 0.39 \%\end{array}$ & $\begin{array}{l}\text { This study } \\
\text { This study }\end{array}$ \\
\hline
\end{tabular}

$W W$ wastewater, $C O D_{I N}\left(C O D_{E F}\right) C O D_{R E} C O D$ influent $(\mathrm{mg} / \mathrm{L})$, effluent $(\mathrm{mg} / \mathrm{L})$ and removal efficiency (\%), respectively, Max. $P(I) C E$ maximum power density as $\mathrm{mW} / \mathrm{m}^{2}$ (current density, $\mathrm{mA} / \mathrm{m}^{2}$ ) coulombic efficiency (\%)

S-MFC single chamber MFC, D-MFC double chambered MFC, SE-MFC submerged-exchangeable-MFC, MFC- $1^{\text {An }}$ anaerobic-D-MFC-1, FAB-1 ${ }^{\text {An }}$ anaerobic-D-FAB-MFC-1, $M F C-1^{A}$ aerobic-MFC-1, FAB-1 ${ }^{A}$ aerobic-D-FAB-MFC-1

Bar shows not reported or could not be calculated from the given information; $d$ shows day, $\mathrm{h}$ for an hour

PTFE polytetrafluoroethylene, IVCW-MFC integrated vertical flow constructed wetland-MFC, $P E M$ proton exchange membrane, $C E M$ cation; exchange membrane, $M B R$ membrane bioreactor, $A-M F C$ (FAB) aerobic-MFC (FAB), An-MFC (FAB) anaerobic-MFC (FAB), FAB fragmented anode biofilm 
Factors affecting MFC performance are external resistor, substrate, $\mathrm{DO}, \mathrm{pH}$, and microbial diversity (Lin et al. 2013). Hence, it could be due to the $\mathrm{COD}_{\mathrm{IN}}$ load variation.

On the other hand, it might arise due to the feeding technique attributed to oxygen contamination and wastewater. The MFC anode reaction products could not be electron alone and include gases such as $\mathrm{CO}_{2}, \mathrm{NH}_{4}^{+} \mathrm{N}$, $\mathrm{CH}_{4}$, and $\mathrm{H}_{2}$ (Abbassi et al. 2020; Li et al. 2013; Santoro et al. 2017). The selective COD and ammonia removal are crucial to increase the MFC performance (Lin et al. 2013). Hence, removing the anode byproducts might reduce the competition between exoelectrogens and other anaerobic microbes such as methanogens.

\section{Performance of aerobic-MFC}

Figure 5 shows the COD concentration in the influent and effluent of the aerobic-MFC system. MFC can be operated from 22 to $127,500 \mathrm{mg} / \mathrm{L}$ COD (Zhang et al. 2009). The average $\mathrm{COD}_{\mathrm{IN}}$ observed in MFC-1 (755 mg/L), MFC-2 (456 mg/L), and MFC-3 (265 mg/L) fall within the recommendable MFC $\mathrm{COD}_{\mathrm{IN}}$ range. Like the anaerobic-MFC, the $\mathrm{COD}_{\mathrm{EF}}$ declines as the pretreatment level increases: MFC-1>-2>-3. The aerobic-MFC integrated system $\mathrm{COD}_{\mathrm{RE}}$ was $(84-97 \%)$ better than solitary MFC (68-78\%) treatment at a steady state.

The highest $C O D_{\mathrm{RE}}$ was observed in aerobic-MFC than the anaerobic-MFC system, but lower voltage generation. This contradictory effect indicates the major portion of $\mathrm{COD}_{\text {IN }}$ might not be used for voltage generation instead consumed by aerobes, or the generated $\mathrm{e}^{-}$was removed via an $\mathrm{e}^{-}$acceptor such as oxygen in the aerobic-MFC system. Li et al. (2013) suggested feeding low-strength wastewater into MFC directly and to apply (anaerobic) pretreatment for high-strength wastewater. Hence, from an energy performance point of view (practical voltage generation), wastewater with $\sim 800 \mathrm{mg} / \mathrm{L} \mathrm{COD}_{\mathrm{IN}}$ might be sound if MFC was applied before the aerobic treatment (MFC-aerobic better than aerobic-MFC).

The voltage generation decreases when the aerobic treatment sequence before MFC increases (MFC-1>-2>-3). The highest voltage production by the MFC-1, -2 and -3 were $0.51,0.42$, and $0.23 \mathrm{~V}$, respectively (Fig. 8). Inconsistent with the findings, Chen et al. (2019) observed $0.5 \mathrm{~V}$ using novel MBR-MFC at a similar $1 \mathrm{k} \Omega$ external load. The voltage declines in MFC-2 might be mainly attributed to the aerobic influent wastewater condition and associated $\mathrm{COD}_{\mathrm{IN}}$ decline, which affects the electroactive microorganisms. These microbes are sensitive to DO, oxidize organic matter under anaerobic conditions, and release electrons to the anode (Logan 2008). However, despite lower DO in the MFC-3 (data not shown), the voltage output decreases due to enhanced

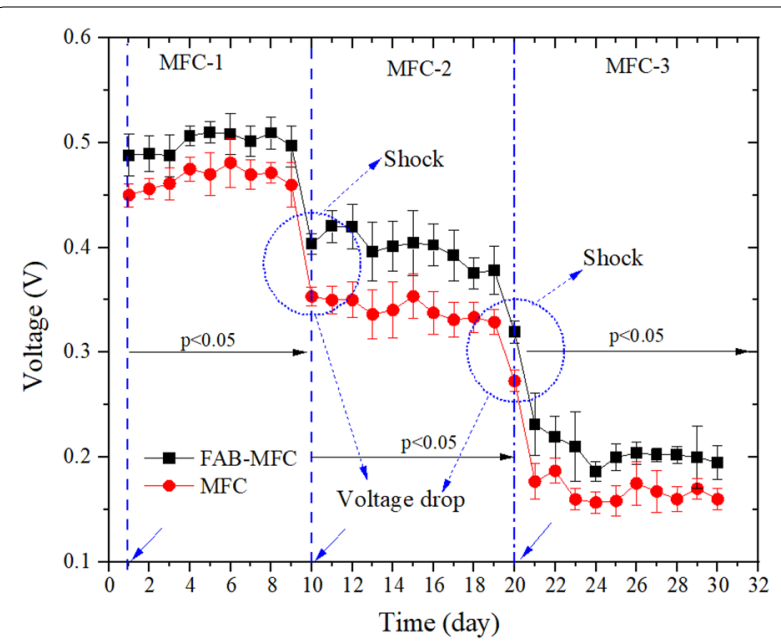

Fig. 8 The voltage generated in the aerobic-MFC integrated domestic wastewater treatment system. Error bars indicate the standard deviation (SD). External load $1000 \Omega$. The $p<0.05$ indicates a significant difference between the FAB-MFC and MFC. A circle with arrows indicates wastewater replacement and system shock

COD removal during the pretreatment. Overall, the voltage generation declined as the influent pretreatment increases. In agreement, Zhang et al. (2013) noted integrating MFC with denitrifying system improves nitrate removal, but lowers energy output.

The MFC-1 MPD was higher than MFC-2 and -3. It was 87 and $78 \mathrm{~mW} / \mathrm{m}^{2}$ in FAB and MFC, respectively, at the maximum current density of $171 \mathrm{~mA} / \mathrm{m}^{2}$ (FAB) and $161 \mathrm{~mA} / \mathrm{m}^{2}$ (MFC). These results were in accordance with $\mathrm{Yu}$ et al. (2012) that noted MPD of 116-149 $\mathrm{mW} / \mathrm{m}^{2}$ from low-strength domestic wastewater $\left(\mathrm{COD}_{\mathrm{IN}}=100 \mathrm{mg} / \mathrm{L}\right)$, and Chen et al. (2019) studied a novel MBBR-MFC integrated system and reported MPD of $95 \mathrm{~mW} / \mathrm{m}^{2}$ at 1 day HRT. However, it is lower than 264 $\mathrm{mW} / \mathrm{m}^{2}$ MPD reported by Wen et al. (2009) while operating brewery wastewater, $\mathrm{COD}_{\mathrm{IN}}=627 \mathrm{mg} / \mathrm{L}$. The MPD declines in the integrated system of MFC-2 $(\mathrm{FAB}=59$ $\left.\mathrm{mW} / \mathrm{m}^{2}, \mathrm{MFC}=42 \mathrm{~mW} / \mathrm{m}^{2}\right)$ and $\mathrm{MFC}-3(\mathrm{FAB}=18 \mathrm{~mW} /$ $\mathrm{m}^{2}, \mathrm{MFC}=12 \mathrm{~mW} / \mathrm{m}^{2}$ ) (Table 2). This declining trend could be due to upstream pretreatment that decreased organic content in the MFC-2 and - 3 influent. Power density decline with decreased external resistance could be due to limited $\mathrm{e}^{-}$transfer to the cathode at higher external load (Zhu et al. 2011). FAB power output betterment could be due to thick $E A B$, which may reduce ohmic loss unlike the packed bed granules and ease substrate diffusion into $\mathrm{EAB}$, consequently hampering the $\mathrm{DO}$ effect.

In MFC-1, at startup, the FAB-MFC (FAB+) voltage generation was $0.04 \mathrm{~V}$ higher than MFC; after 6 days of operation, the gap narrows to $0.03 \mathrm{~V}$ (Fig. 8). The $\mathrm{EAB}$ requires an optimum of 7 days to grow on the MFC 


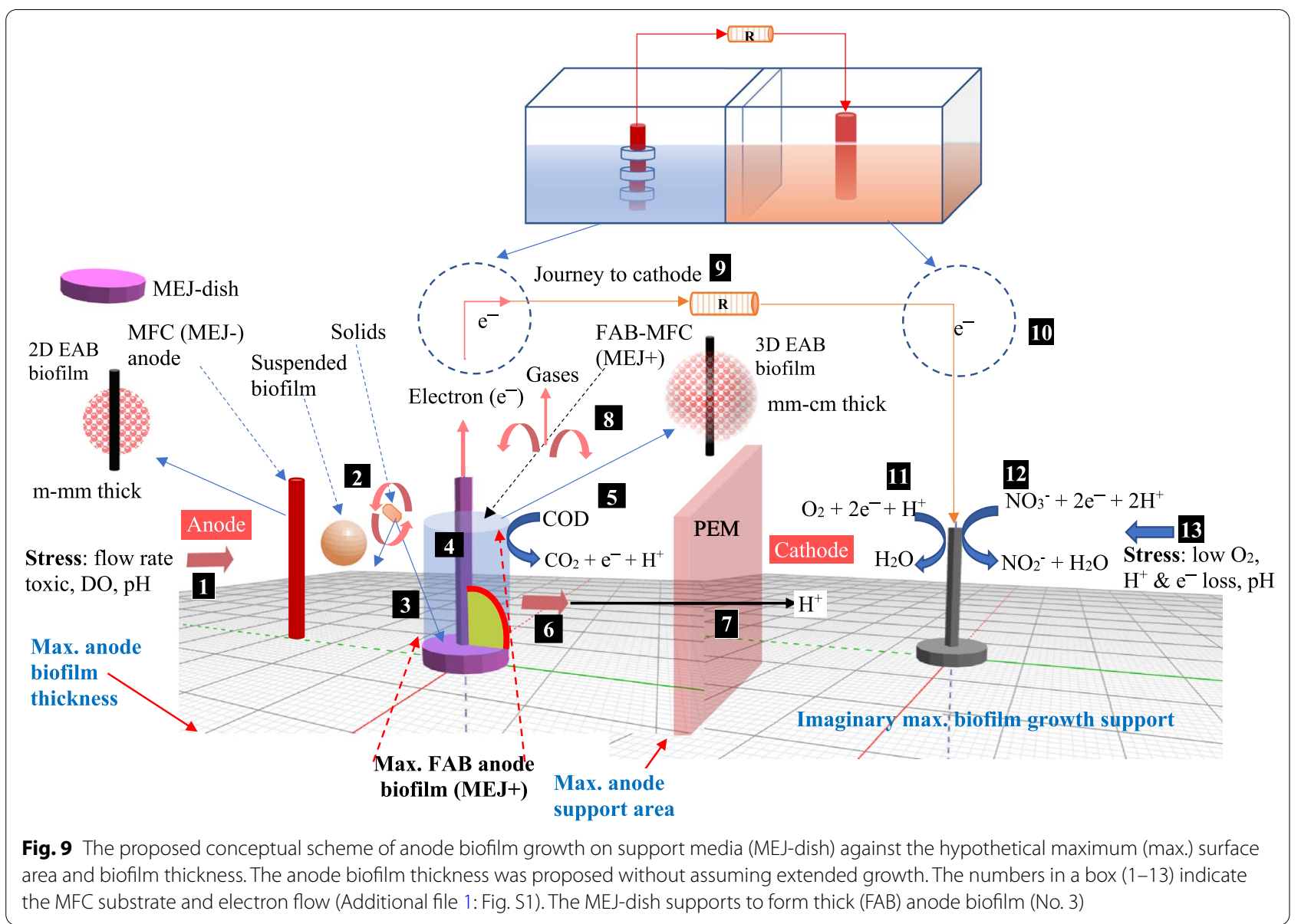

anode surface (Arbianti et al. 2018). FAB (MEJ+) might speed up the $E A B$ colonization and growth, but against this case, all the setups were operated for more than a month to reach a steady state before the experiment startup (variation $<0.01 \mathrm{~V} / \mathrm{h}$ ). Hence, most likely, the thick biofilms formed on the FAB anode withstand aerobic influent shock and stabilize voltage generation. Like the anaerobic-MFC, the aerobic-MFC voltage generation was affected during phase interchange. In the aerobicMFC integrated system, the FAB + reduces the voltage drop by $14 \mathrm{mV}$ than MFC.

The MFC-2 MPD difference between FAB + and MFC in aerobic-MFC $\left(17 \mathrm{~mW} / \mathrm{m}^{2}\right)$ was $\sim 3$ times higher than anaerobic-MFC $\left(7 \mathrm{~mW} / \mathrm{m}^{2}\right)$. Hence, the FAB critical role was revealed when the MFC was exposed to anaerobically treated influent. This finding supports, the thick anode biofilms might be valuable for the EABs' functional stability during DO intrusion. The observed data suggest an interaction effect between the thick anode biofilm, $\mathrm{COD}_{\mathrm{IN}}, \mathrm{EAB}$, and $\mathrm{DO}$ on $\mathrm{FAB}+$ bioelectricity generation and treatment performance.

\section{Effect of FAB on MFC-integrated system performance}

Figure 9 displays the MEJ+(FAB) proposed biofilm growth against MEJ- (MFC) anode. The conceptual scheme shows that the MEJ-dish was designed to support EAB growth and increase anode biofilm thickness. As expected, fragmented (thick and thin) anode biofilms were observed in FAB than MFC (Additional file 1: Fig S9). Of course, the biofilm thickness on the MFC anode was heterogeneous and varied across the surface; however, the FAB magnifies this variation into a significant difference (Fig. 10). Similarly, Li et al. (2016) reported thick electrical conductor biofilm. The present study did not determine the biofilm electrical conductance, despite previous studies suggesting centimeter-long biofilm conductivity. The anode biofilm structures are dependent on anode materials (Nevin et al. 2008), more bacterial adhesion linked with more thick biofilm, and lower electrical loss (Nosek et al. 2020). Hence, the FAB peculiar anode biofilm structure could be due to MEJ-dish.

The FAB anode average biofilm thickness was $\sim 5$ times higher than MFC in anaerobic-MFC (FAB $=188 \pm$ $67 \mu \mathrm{m}, \mathrm{MFC}=43 \pm 17 \mu \mathrm{m})$ and aerobic-MFC $(\mathrm{FAB}=$ 

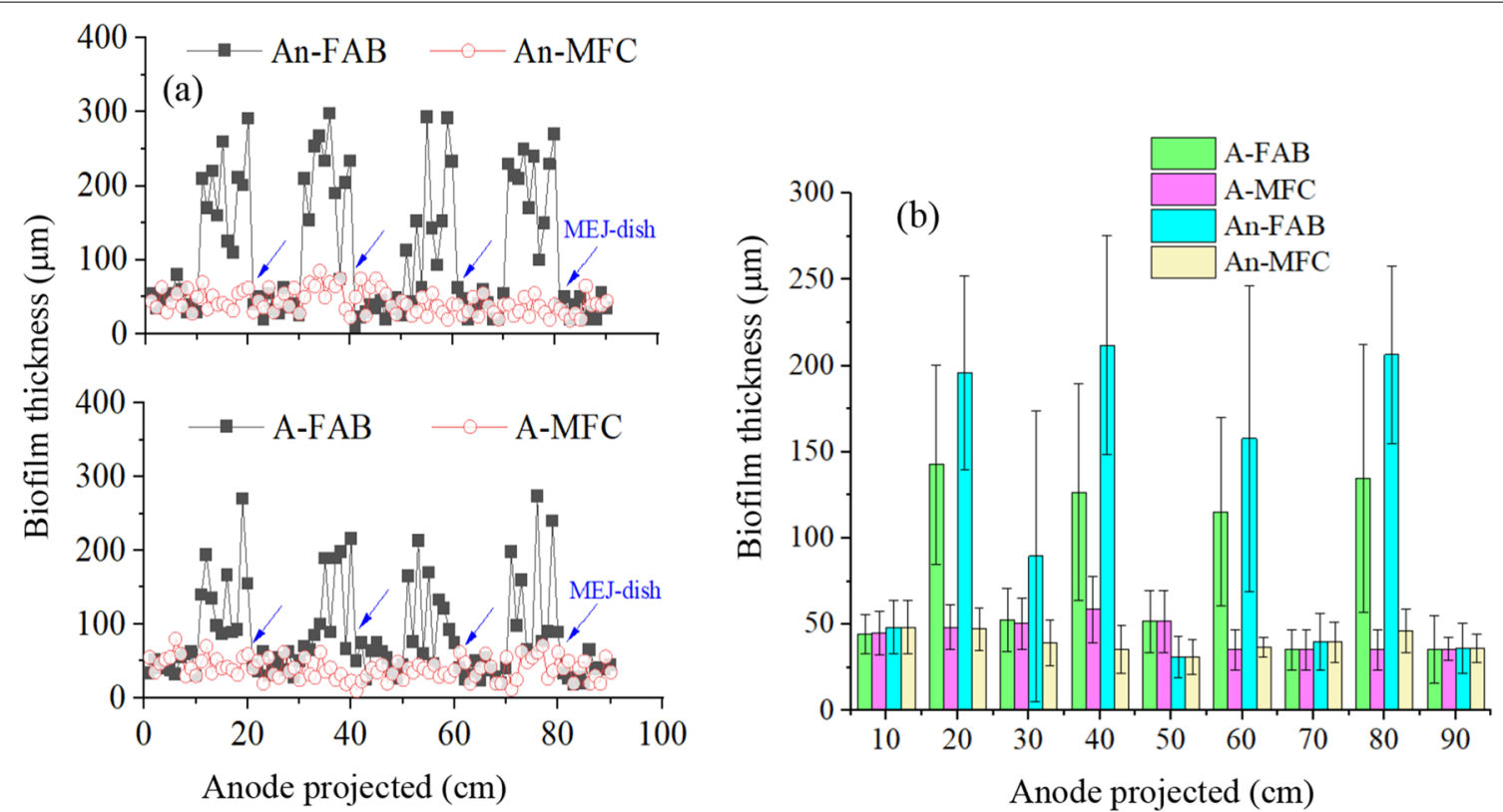

Fig. 10 The anode biofilm thickness (BT) profile in the aerobic-MFC (A-FAB and A-MFC) and anaerobic (An-Fab and An-MFC) integrated system. The overall $\mathbf{a} B T$ distribution and $\mathbf{b}$ mean \pm SD. Each data point indicates the top BT within multiple measurements of $n$ independent biofilms $(5 \leq n \leq 10)$ per $10 \mathrm{~mm}$ distance excluding outliers, but not the exact spatial and temporal BT distribution on the electrode. The arrows indicate MEJ-dish inserted location on the anode. FAB fragmented anode biofilm

$127 \pm 62 \mu \mathrm{m}, \mathrm{MFC}=40 \pm 14 \mu \mathrm{m}$ ) (Fig. 10). These values were within previously reported average anode biofilm thickness: $66 \pm 16 \mu \mathrm{m}$ (Lee et al. 2009), $42 \pm 3 \mu \mathrm{m}$ (Read et al. 2010), and $150 \mu \mathrm{m}$ (Millo 2015). G. sulfurreducens form $\mathrm{EAB}$ that conduct $\mathrm{e}^{-}$about $100 \mu \mathrm{m}$ thick (Malvankar et al. 2011). However, $\mathrm{Li}$ et al. (2016) reported a $1 \mathrm{~mm}$ conductor biofilm length $(10 \times)$ using mixed species. Infrequently, the biofilm on the MEJ-dish reaches a centimeter long (Additional file 1: Fig. S8), which might be due to biofilm detachment. It shows the proposed FAB method could support the EAB life cycle from attachment-to-detachment (genesis-to-end). Due to unknown reasons, the biofilm thickness in anaerobic-MFC was thicker than aerobic-MFC. This thickness variation might be due to lower synergetic association in the aerobic exposed anode. Hence, exposing the anode biofilm to aerobic influent might slice the thickness.

This study was not the pioneer to report a centimeterlong biofilm. Bacteria develop a wide range of biofilm thickness; for example, Bacillus subtilis cultured on agar media form $600 \mu \mathrm{m}$ thick and $1.2 \mathrm{~cm}$ long (Wang et al. 2015), 200-500 $\mu \mathrm{m}$ on MBBR filter carrier media (Piculell et al. 2016). Using the SAHB approach, Nakamura et al. (2009) added $\alpha-\mathrm{Fe}_{2} \mathrm{O}_{3}$ into Shewanella to develop a thick anode biofilm. But the technical viability to practical application remains a challenge. The FAB presents a simple method by making a micro or macrostructure on the electrode surface to enlengthen the EAB thickness. Unlike so far reported, the FAB surface topography is a removable electrode jacket (coated), which supports the EAB life cycle and easily regenerates the electrodes. However, it was not without demerit that requires optimizing the MEJ-dish type (size) that affects the junction point while socketing with the electrode. It covers the contact surface, creates a blind spot (prevents biofilm growth and $\mathrm{e}^{-}$collection on the surface), and affects power output efficiency. In addition, the pore structure on the top side of $\mathrm{K} 3$ filter media probably discourages further biofilm enlargement on MEJ-dish. These MEJ-biofilm-electrical effects could be a subject for future studies and debate.

The FAB thick anode biofilm formation might provide a multilayer advantage. Thick anode biofilm formation and high current production is associated with pili that contribute to the $\mathrm{e}^{-}$transfer to the anode (Nevin et al. 2008) and reduce competition between oxygen and anode $\mathrm{e}^{-}$ acceptor (Nosek et al. 2020). The extracellular biofilm heteropolysaccharides and $c$-type cytochrome protein complex transfer $\mathrm{e}^{-}$to the anode (Santoro et al. 2017). Probably, the interdependent function of biofilm materials such as EPS and pili complex could enhance the $\mathrm{e}^{-}$ transfer in the FAB-MFC. On the other hand, suspended microbes, including the electroactive bacteria, might degrade the organic matter or release $\mathrm{e}^{-}$into the surrounding vicinity; if the released $\mathrm{e}^{-}$was in the distance 
to reach anode or conductive biofilm, $\mathrm{e}^{-}$might be collected. FAB might contribute to these processes due to increased anode biofilm thickness. For example, You et al. (2015) noted that suspended microbes, even if not generated $\mathrm{e}^{-}$, might degrade the organic matter that $\mathrm{EAB}$ can later consume. In contrast, as the thickness increases further, the $\mathrm{e}^{-}$transfer might be affected. Current studies indicate metal-like conductivity in the EABs and $\mathrm{e}^{-}$conductivity about a centimeter distance from the electrode (Malvankar et al. 2011; Yuan et al. 2020). However, this idea remains debatable as a practical means to prove the hypothesis in a ongoing research (Strycharz and Tender 2012).

Against the hypothesis, in the anaerobic-MFC system (MFC-3), the immense benefit of FAB thick anode biofilm seems ineffective to improve $\mathrm{e}^{-}$collected at the anode. Unlike MFC- 1 and -2 , in -3 the power output and CE becomes negligible $(p>0.05)$ between FAB and MFC. This inconsistency might occur due to insufficient fuel to supply the developed thick anode biofilm (Fuel/EAB) (i.e., it may create an inactive zone) and corresponds with the anode to volume ratio $(A / V)$. These results indicate that the enhanced EAB growth should be examined under several pretreatments with controlled complex system stressing conditions. Otherwise, it can mislead the conclusion that enhanced EAB formation could not boost power yield. Probably, this might be a remarkable reason that obscured a milestone power output and $C E$ achievement in previous studies.

Voltage drops at the end of each treatment cycle and the onset of the consequent phase. Similar patterns were reported elsewhere (Su et al. 2013; Ye et al. 2019). Voltage perturbation was more recurrent in the aerobic-MFC relative to the anaerobic-MFC. Hence, this result suggests the FAB system contributed more to aerobic-MFC integrated treatment than the anaerobic-MFC system. It could be due to DO shock from the aerobic reactor that destabilizes the MFC system compared with anaerobicMFC. The causes of voltage drop in the MFC-integrated wastewater treatment system are diverse: oxygen diffusion to the anode, $\mathrm{pH}$ (59 $\mathrm{mV}$ loss/unit change), COD shock arising from the subsequent reactor to the MFC, starvation, and abiotic factors such as internal resistance (Gajaraj and $\mathrm{Hu}$ 2014; Oh and Logan 2007). EABs have reversible hydrogenase enzymes that switch extra cellular $\mathrm{e}^{-}$release processes to capture $\mathrm{e}^{-}$inside the cell, resulting in a voltage drop (He et al. 2017). It is essential to build thick anode biofilm and optimize the operational condition (He et al. 2017; Sun et al. 2016). Therefore, the thick biofilms on the FAB electrode might reduce the oxygen effect on the exoelectrogen bacteria.

Figures 7 and 8 show that the voltage generation decreases when the $\mathrm{COD}_{\mathrm{IN}}$ declines except for MFC-2 in the anaerobic-MFC system. The substrate shock (fuel: COD) in both the aerobic-MFC and anaerobic-MFC was accompanied by voltage drop, but consequently, there was a variation in the voltage output. After the shock, voltage increase in the anaerobic-MFC system (MFC-2) but declines in aerobic-MFC. It might be due to oxygen intrusion from the aerobic reactor effluent, which signals within a certain COD range; the DO level could be more critical to determine the voltage output and drop. Aerobic treatment is the most efficient system for extracting the energy stored in the substrate than methanogenesis and fermentation; Gibbs free energy change $\left(\Delta G^{0}\right)$ for glucose oxidation was $-2882,-428,-342 \mathrm{~kJ} / \mathrm{mol}$, respectively (Comeau 2008). Hence, aerobic pretreatment, low $\mathrm{COD}_{\mathrm{IN}}$, high $\mathrm{DO}$, and inoculant nature might cause the MFC-2 decrease in aerobic-MFC than the anaerobic-MFC system.

The maximum coulombic efficiency (CE) observed in anaerobic-MFC $(0.91 \%)$ was higher than in the aerobic-MFC system (0.80\%) (Table 2). Similar 1\% CE was recorded by Zhang et al. (2009), but a higher CE (3-12\%) was noted by Liu and Logan (2004). Lower CE is an issue in real wastewater treatment using MFC ( $\mathrm{Lu}$ et al. 2009). Cofactors may result in CE loss: aerobic pretreatment (lower $\mathrm{COD}_{\mathrm{IN}}$ ) and several final $\mathrm{e}^{-}$acceptors (DO, $\mathrm{NO}_{3}^{-}$, and $\mathrm{SO}_{4}^{2-}$ ). Anaerobic processes such as methanogenic and anaerobic ammonia oxidation (Anammox) may shift the $\mathrm{e}^{-}$pathway and reduce CE. The DO may result in additional harm to the strict anaerobic EAB. The CE difference between FAB and MFC was negligible (0.01-0.12\%); this might be $\triangle C O D$ could not be differentiated because both systems were operated in the same reactor. In another optimization setup (data not shown), FAB and MFC were placed in a separate reactor, and FAB improved CE by 10\% beyond MFC. However, this could be a potential research question for future studies.

At a steady state, the $\mathrm{COD}_{\mathrm{EF}}$ in the solitary MFC was above $200 \mathrm{mg} / \mathrm{L}$. In contrast, MFC-integrated system reduces $\mathrm{COD}_{\mathrm{EF}}$ below $125 \mathrm{mg} / \mathrm{L}$, which was $82-124 \mathrm{mg} / \mathrm{L}$ (MFC-2) and 52-27 mg/L (MFC-3) (Fig. 5). Standalone $\mathrm{MFC}$ requires further treatment to meet the $\mathrm{COD}_{\mathrm{EF}}$ discharge standard, $50 \mathrm{mg} / \mathrm{L}$ (China) and $20 \mathrm{mg} / \mathrm{L}$ (Korea) (Yu et al. 2012). This finding was in agreement with Ren et al. (2014), MFC treated domestic WWT COD ${ }_{\mathrm{EF}}$ ranges 23-164 mg/L (fed-batch) and 60-220 mg/L (continuous) based on HRT, reactor configuration, and $\mathrm{COD}_{\mathrm{IN}}$. When the pretreatment increases (1-2 days) at the same HRT of 1 day in MFC, the $\mathrm{COD}_{\mathrm{EF}}$ declines. It might be due to the diverse microbial population contributing to the organic matter degradation, extended HRT, or enhanced nutrient mixing during substrate was transferred from one reactor to another. The $\mathrm{COD}_{\mathrm{IN}}$ fluctuation on day 12 (MFC2 ) was caused by sludge resuspension, stabilized after the 
flow rate was restored. The experimental data support the novel FAB-MFC system better reduce voltage drop than MFC; however, the $\mathrm{COD}_{\mathrm{RE}}$ could not be concluded because both FAB and MFC systems were inserted in the same reactor and operated under similar near anodic $\mathrm{pH}$. Nevertheless, the aerobic-MFC $\mathrm{COD}_{\mathrm{RE}}$ outweighs the anaerobic-MFC system. Overall, the MFC-integrated system $\mathrm{COD}_{\mathrm{RE}}$ was $(78-97 \%)$ higher than the solitary MFC $(68-78 \%)$ treatment. These $\mathrm{COD}_{\mathrm{RE}}$ results are in line with other studies on MFC-integrated systems (66-97\%) (Chen et al. 2019; Gajaraj and $\mathrm{Hu}$ 2014) and standalone MFC (22-80\%) (Kim et al. 2016; Liu and Logan 2004) (Table 2). In MFC, $C O D_{\mathrm{RE}}$ depends on $\mathrm{COD}_{\mathrm{IN}}$ type; from the total COD (tCOD) biofilms prefer the soluble COD (sCOD) than particulate COD (pCOD) (Ren et al. 2014). Hence, this study elevated $\mathrm{COD}_{\mathrm{EF}}$ could be due to higher pCOD in the system.

The $\mathrm{COD}_{\mathrm{RE}}$ and $\mathrm{CE}$ during the treatment period are shown in Fig. 6. As shown in the figure, in MFC, the $\mathrm{COD}_{\mathrm{RE}}$ increases with an integrated system, $\mathrm{MFC}-1<-2<-3$. In particular, the $\mathrm{COD}_{\mathrm{RE}}$ in aerobic and anaerobic-MFC integrated system was $71-74 \%$ in MFC-1 $\left(\mathrm{COD}_{\mathrm{IN}}=755 \mathrm{mg} / \mathrm{L}\right), 75-78 \%$ in MFC-2 $\left(\mathrm{COD}_{\mathrm{IN}}=456-\right.$ $500 \mathrm{mg} / \mathrm{L})$, and $84-85 \%$ in $\mathrm{MFC}-3\left(\mathrm{COD}_{\mathrm{IN}}=265-\right.$ $351 \mathrm{mg} / \mathrm{L})$. CE decreases with COD removal increases. $\mathrm{CE}$ bears a resemblance to electricity generation than $\mathrm{COD}_{\mathrm{RE}}$. The cause behind inverse $\mathrm{CE}$ and $\mathrm{COD}_{\mathrm{RE}}$ association is unknown (Yu et al. 2012); however, the factors might be $\mathrm{e}^{-}$loss in the system due to endoelectrogens or biofilm conductivity problems. Carbon $\left(\mathrm{e}^{-}\right)$balance study implicates $\mathrm{SO}_{4}^{2-}$ reduction $(37-64 \%)$ is the major $\mathrm{e}^{-}$scavenger followed by methanogens $(1.3-3 \%)$ (Zhang et al. 2013).

Additional MFC-integrated system advantage could be stabilized influent to the electroactive bacteria $\left(\mathrm{SD}=12-23 \mathrm{mg} / \mathrm{L} C \mathrm{CD}_{\mathrm{IN}}\right.$ ), relative to (raw WW) directfed MFC $\left(\mathrm{SD}=52 \mathrm{mg} / \mathrm{L} \mathrm{COD}_{\mathrm{IN}}\right)$. This stability may arise from influent steady-state nature: partially treated, anaerobic, and intermediate metabolites. In contrast, You et al. (2015) reported stability of standalone MFC (anodic biofilm) under different feedstock conditions. This variation could arise from DO during pretreatment in this study, while the authors change the substrate (acetate and casein).

The improved anode surface area (ASA) should support the EAB life cycle, an overlooked part in ASA modification, especially the detachment means from the electrode. The biofilm formation comprises three basic stages: attachment, maturation, and detachment from the electrode surface (Read et al. 2010). The lipopolysaccharides (LPS) and exopolysaccharides (EPS) are crucial for biofilm formation. In EAB, the EPS attaches cell to cell over the electrode-recent pieces of evidence support the electrical conductivity nature of EPS in MFC (Angelaalincy et al. 2018). According to Yu et al. (2017), one of the critical concerns of 3D electrodes fabricated using nanotechnology was the small pore size forbids interior biofilm growth. The microbial electrode pore size should not be $<100 \mu \mathrm{m}$ as the biofilm thickness is $30-50 \mu \mathrm{m}$ on average. This nanopore size might not develop a centimeter-long biofilm, where recent studies recommend thick anode biofilm (Malvankar et al. 2011). In addition, the electrode reusability was neglected (regenerate MFC), while the focus was on ASA and pore size improvement. Dead bacteria may attach to the electrode and interfere with MFC performance (Sun et al. 2016). Hence, as the pore size narrows, dead biomass may deposit and block material and $\mathrm{e}^{-}$flow. Consequently, it becomes difficult to re-use the electrode via a simple technique such as rinsing with water, scrapping, adjusting the flow rate, or increasing the electrode cleanup cycle.

Despite further studies, the MEJ-dish approach enables thick anodic biofilm growth and easy removal of the MEJdish and biofilm; again, re-sizing the dish could monitor the EAB growth. However, the limitation of this study was examining the MEJ+ and MEJ- electrodes in the same reactor. For instance, $\triangle C O D$ could not be differentiated between FAB + and MFC systems. Ultimately, this effect may obstruct the performance difference between the two systems; hence, future studies might consider a separate reactor with different MEJ-dish, wastewater, or inoculum.

In general, these findings implicate, anode modification with MEJ-dish (FAB) improves the power output. Similarly, Zhou et al. (2012) noted that enhancing anode area improves the MFC performance. Against this conclusion, Di Lorenzo et al. (2010) observed anode surface increment with granulated packed graphite pellets did not increase the current output due to mass distribution. Hence, increasing ASA alone could not always ensure performance increment. Probably, the increased ASA was not suitable for the EAB growth, results in discontinuous EAB formation, fuel (substrate) could not reach the modified area as it is far away from the external surface, or narrow pore size (due to packing or nano-modification) that can be easily clogged by solids in the liquid.

\section{Comparison of FAB-MFC integrated systems with other studies}

The MFC-integrated systems performance was compared with other studies (Table 2). The results observed in this study were comparable with previously reported findings (Chen et al. 2019). The mean $\mathrm{COD}_{\mathrm{RE}}$ observed in this study (71-95\%) was higher than Goto and Yoshida (2019) (49\%) but closer to Liu et al. (2019) (80\%) findings. However, it might be challenging to 
make a solid conclusion due to variation in MFC setups and $\mathrm{COD}_{\mathrm{IN}}$. In addition, the previous study reactor volume ranges from 0.18 to $40 \mathrm{~L}$, external load varies from 3 to $1000 \Omega$ and MFC configuration (Goto and Yoshida 2019; Liu et al. 2019; Wen et al. 2009).

The power density observed in standalone MFC was $\sim 3$ times lower than in Liu and Logan (2004) because the authors used PEM (Nafion) with lower resistance than the salt bridge used in this study. For example, Min et al. (2005) noted internal resistance of PEM $(1.3 \mathrm{k} \Omega)$ was $\sim 15$ times lower than the salt bridge $(20 \mathrm{k} \Omega)$. In addition, the authors used glucose substrate, but real wastewater has several $\mathrm{e}^{-}$acceptors that lower the power efficiency. On the other hand, the power density observed in this study was higher than $0.3 \mathrm{~mW} / \mathrm{m}^{2}$ by Min et al. (2005) using a salt bridge and pure culture (G. metallireducens). Power output variation may arise from the inoculum (Ishii et al. 2017; Santoro et al. 2017; Xu et al. 2016). Even the mechanism of salt bridge synthesis affects the power output; as Sevda and Sreekrishnan (2012) noted, increasing salt concentration up to $5 \%$ raises proton transfer capacity, lowers internal resistance, and improves the power output by $\sim 11$ times. The power output observed in this study was $\sim 4$ times higher than that in Rodrigo et al. (2007); since information on salt bridge synthesis was not provided, further discussion could not be made.

Compared to the standalone MFC (MFC-1), the aerobic-MFC integrated (MFC-2 and -3) system generated lower power output. The cause might be the aerobic treatment that reduces the MFC influent fuel concentration or results in DO contamination. But, the anaerobicMFC system influent prompts MFC-2 beyond MFC-1 and -3. Overall, anaerobic influent better stabilizes influent and enhances the performance. Similar effects were reported by Chen et al. (2019); Li et al. (2015); and Yadav et al. (2012). In contrast to Bose et al. (2018); Kalathil et al. (2013); and Rodrigo et al. (2007), the present study did not apply aeration to the cathode. Another advantage of this system is using a hybrid cathode, oxygen in the air, and tap water as an $\mathrm{e}^{-}$acceptor. If the hybrid-cathode were not used, aeration might be required. Vicari et al. (2016) observed $81 \%$ of DO (3-0.57 mg/L) was consumed within less than an hour in the cathode chamber. That is why the reported D-MFC with oxygen as $\mathrm{e}^{-}$acceptor was obliged to aerate the cathode chamber (Table 2).

\section{Applications of FAB-MFC}

This study presented a simple, practical technique (FAB) to increase anode surface area that influences the anode biofilm structure without chemical or thermal modification. It was evaluated in different MFC configuration systems. For example, metal electrodes are more $\mathrm{e}^{-}$conductors, but the major limitation is microbial attachment surface area; hence, etched with sulfuric acid (Nosek et al. 2020). In the FAB reactor, the junction point between MEJ-dish and electrode is crucial. This area has a determinant limitation for additional $\mathrm{e}^{-}$collection, affecting bioelectricity production, particularly at startup. In our previous study, several MEJ-dishes with different junction types: open, partly open, and closed for EAB growth were examined (Atnafu and Leta 2021). The MEJ-dish (e.g., K3) with open junction space for EAB growth yields a fascinating result; naked eye-observable thick biofilm supersedes MFC voltage output (max open circuit $0.9 \mathrm{~V}$ ) and is vital at later age of the reactor during stress such as organic matter depletion.

In contrast, the MEJ-dish covered junction point lowers voltage output at startup and extends the period to reach a steady state. One of the peculiar features we notice is that MEJ-dish might create a small pocket of a strict anaerobic zone where the EAB favors colonizing. Of course, it might attract competitors and results against the expectation. Most review papers on MFC suggest the need for innovative paradigm shift and study on electrode fabrication, configuration, and operation (Yu et al. 2017). Future studies might need to develop creative MEJ-dish to support EAB growth.

On the other hand, questions may be raised on FAB practicality. In pure culture study, the biofilm thickness was electrochemically active in $\sim 20-50 \mu \mathrm{m}$ thick (Sun et al. 2016), so why is the need to increase beyond? Even if the anode biofilm thickness increases, the electrical efficiency might be compromised due to electrode overpotential, ohmic loss, activation loss, parasitic loss, current, and mass distribution (Choudhury et al. 2017; Di Lorenzo et al. 2010)?

Addressing these issues, recent studies by Yuan et al. (2020) and Malvankar et al. (2011) indicate anode biofilm tendency to transmit $\mathrm{e}^{-}$over a centimeter long. Mixed culture increases biofilm thickness and minimizes oxygen diffusion to the inner EAB layer (Yang et al. 2019) and results in a synergetic effect than pure culture (Goto and Yoshida 2019; Logan 2008). Additionally, it could be possible to manage the biofilm thickness by re-sizing the MEJ-dish. Extra electrode biofilm growth and removable cleaning part (MEJ-dish) might ease the electrode cleaning using simple techniques such as shear force and flow rate. The MFC performance strongly depends on anode geometry (Merkey and Chopp 2012). Hence, the HDMEJ+ approach might enable a simultaneous advantage of multi-dimension electrodes in a single design.

According to Yu et al. (2021) and Zhang et al. (2013), even if MFC bioelectricity generation is not enhanced, improving treatment performance is outstanding achievement. In fact, increasing anode surface and 
biofilm thickness alone, to any required degree, could not lift the electrical output unless associated factors address from power generation to collection. However, it may contribute a small step toward filling the anode biofilm growth drawbacks. Supporting the argument, Choudhury et al. (2017) suggested that novel electrode design or surface modification (physical or chemical) enhances $\mathrm{e}^{-}$conductivity and bacterial adhesion. Overall, given further studies, the FAB concept introduces novel HD microbial electrode design such as T-shape electrode (MEJ-dish + electrode $=$ flexible hybrid 3D electrode) rather than plain, flat, rod-shaped, or fixed 3D electrode (carbon foam/brush) that could dominate the current MFC research.

\section{Conclusions}

In this study, a novel fragmented anode biofilm microbial fuel cell (FAB-MFC) integrated system was developed and investigated for domestic wastewater treatment and bioelectricity generation. The anode with microbial electrode jacket dish (MEJ-dish) was designed to enhance anode biofilm growth and system performance. FAB (MEJ+) and MFC (MEJ-) were compared for power output performance. The FAB enabled variable (thick and thin) biofilm formation compared to MFC. The FAB simple, straightforward technique increases anode biofilm thickness $\sim 5$ times a bare electrode. The FAB-MFC (FAB+) integrated system improved the COD removal compared with solitary MFC. However, it was impossible to conclude the FAB $+\triangle \mathrm{COD}$ and $\mathrm{CE}$ efficiency because both electrodes (MEJ+and MEJ-) were inserted in the same reactor. The MFC-integrated system power generation was affected with the pretreatment level for $<800 \mathrm{mg} / \mathrm{L} \mathrm{COD} \mathrm{IN}_{\text {at }}$ at $0.76 \mathrm{~kg}-\mathrm{COD} /$ $\mathrm{m}^{3} /$ day load. The anaerobic-MFC integrated system power generation was found significantly higher than the aerobicMFC. The bioelectric generation was greater in solitary (directly fed) MFC than in aerobically treated effluent-fed MFC. The FAB system generates the highest power than MFC in anaerobic-MFC $\left(F A B=104 \mathrm{~mW} / \mathrm{m}^{2}, \mathrm{MFC}=98\right.$ $\left.\mathrm{mW} / \mathrm{m}^{2}\right)$ and aerobic-MFC $\left(\mathrm{FAB}=59 \mathrm{~mW} / \mathrm{m}^{2}, \mathrm{MFC}=42\right.$ $\mathrm{mW} / \mathrm{m}^{2}$ ) integrated system. Voltage drops were noticed during treatment phase transition, and FAB reduces the voltage drop relative to MFC. The FAB+integrated system could be applied for real applications and enhance performance. It might depend on the substrate (COD) load, DO concentration, and microbial diversity in the inoculum. Hence, further studies will be required to understand the $\mathrm{FAB}+$ efficiency in terms of inoculant nature, MEJ-dish type, and electrical conductivity over thick long-distance biofilm.
Abbreviations

ASA: Anode surface area; MFC: Microbial fuel cell; MEJ: Microbial electrode jacket; FAB: Fragmented anode biofilm.

\section{Supplementary Information}

The online version contains supplementary material available at https://doi. org/10.1186/s40643-021-00442-x.

\begin{abstract}
Additional file 1: Fig. S1. The proposed hypothetical presentation of the FAB conceptual model to form thick anode biofilm. Fig. S2. Screening (1), sedimentation (2), and anaerobic reactor (3). Fig. S3. The detailed schematic diagram of the aerobic reactor (R4). Fig. S4. Schematic diagram of H-type air diffuser (a) designed and (b\&c) constructed. Drawings are not to scale. The diffuser was inserted into the aerobic reactor (MBBR). Fig. S5. The FAB-MFC integrated system (a-c) during construction and (d) photo. Fig. S6. The methanogenic reactor (a) schematic diagram and (b) photo. Fig. S7. Ball valve (a) PPR, (b) Brass, (c) PVC, and (d) reactors stand support. Fig. S8. Microbial electrode jacket-dish (designed). $\mathrm{D}=$ dimension. Fig. S9. Schematic diagram of the microbial fuel cell (MFC) integrated domestic wastewater treatment system options (1-3). Fig. S10. Observed biofilm on the MEJ+ electrode.
\end{abstract}

\section{Acknowledgements}

This study was partially supported by the Center for Environmental Science, Addis Ababa University, and Department of Biological science, College of Natural and Computational Sciences, Mettu University, Ethiopia.

\section{Authors' contributions}

TA designed the experimental setup and ran the analysis. SL supervised and evaluated the work and participated during the design and development of the study. All authors read and approved the final manuscript.

\section{Funding}

Not applicable.

\section{Availability of data and materials}

The data sets used in this study are available from the corresponding author on reasonable request.

\section{Declarations}

Ethics approval and consent to participate Not applicable.

\section{Consent for publication}

Not applicable.

\section{Competing interests}

The authors declare that there is no conflict of interest.

\section{Author details}

${ }^{1}$ Center for Environmental Science, Addis Ababa University, Addis Ababa, Ethiopia. ${ }^{2}$ Department of Biological Science, College of Natural Sciences, Mettu University, Mettu, Ethiopia.

Received: 8 June 2021 Accepted: 3 September 2021

Published online: 13 November 2021

\section{References}

Abbassi R, Yadav AK, Khan F, Garaniya V (2020) Integrated microbial fuel cells for wastewater treatment. Butterworth-Heinemann, MA, United States. https://doi.org/10.1016/C2017-0-03157-9

Ahn Y, Logan BE (2010) Effectiveness of domestic wastewater treatment using microbial fuel cells at ambient and mesophilic temperatures. Bioresour Technol 101:469-475. https://doi.org/10.1016/j.biortech.2009.07.039 
Angelaalincy MJ, Navanietha Krishnaraj R, Shakambari G, Ashokkumar B, Kathiresan S, Varalakshmi P (2018) Biofilm engineering approaches for improving the performance ofmicrobial fuel cells and bioelectrochemical systems Frontiers in Energy Research 6:63. https://doi.org/10.3389/fenrg. 2018.00063

APHA (2005) Standard methods for the examination of water and wastewater. 21st edn. American Public Health Association (APHA), American Water Works Association (AWWA), and Water Environment Federation (WEF), Washington DC, USA

Arbianti R, Utami TS, Leondo V, Putri AS, Hermansyah H (2018) Effect of biofilm and selective mixed culture on microbial fuel cell for the treatment of tempeh industrial wastewater MS\&E 316:012073. https://doi.org/10.1088/ 1757-899X/316/1/012073

Atnafu T, Leta S (2021) New fragmented electro-active biofilm (FAB) reactor to increase anode surface area and performance of microbial fuel cell. Environmental Systems Research 10:31. https://doi.org/10.1186/ s40068-021-00234-4

Bakke R, Kommedal R, Kalvenes S (2001) Quantification of biofilm accumulation by an optical approach. J Microbiol Methods 44:13-26. https://doi. org/10.1016/S0167-7012(00)00236-0

Bose D, Dhawan H, Kandpal V, Vijay P, Gopinath M (2018) Sustainable power generation from sewage and energy recovery from wastewater with variable resistance using microbial fuel cell. Enzyme Microb Technol 118:92-101. https://doi.org/10.1016/j.enzmictec.2018.07.007

Brown RK, Harnisch F, Dockhorn T, Schröder U (2015) Examining sludge production in bioelectrochemical systems treating domestic wastewater. Bioresour Technol 198:913-917. https://doi.org/10.1016/j.biortech.2015. 09.081

Chen X, Cui D, Wang X, Wang X, Li W (2015) Porous carbon with defined pore size as anode of microbial fuel cell. Biosens Bioelectron 69:135-141. https://doi.org/10.1016/j.bios.2015.02.014

Chen F, Zeng S, Luo Z, Ma J, Zhu Q, Zhang S (2019) A novel MBBR-MFC integrated system for high-strength pulp/paper wastewater treatment and bioelectricity generation. Sep Sci Technol 55:2490-2499. https://doi.org/ 10.1080/01496395.2019.1641519

Choudhury P, Prasad Uday US, Bandyopadhyay TK, Ray RN, Bhunia B (2017) Performance improvement of microbial fuel cell (MFC) using suitable electrode and bioengineered organisms: a review. Bioengineered 8:471-487. https://doi.org/10.1080/21655979.2016.1267883

Comeau Y (2008) Microbial metabolism. In: Henze M, Loosdrecht V, MC M, Ekama GA, Brdjanovic D (eds) Biological wastewater treatment: principles, modelling and design. IWA Publishing, London, UK, pp 10-32

Di Lorenzo M, Scott K, Curtis TP, Head IM (2010) Effect of increasing anode surface area on the performance of a single chamber microbial fuel. Cell Chem Eng J 156:40-48. https://doi.org/10.1016/j.cej.2009.09.031

Gajaraj S, Hu Z (2014) Integration of microbial fuel cell techniques into activated sludge wastewater treatment processes to improve nitrogen removal and reduce sludge production. Chemosphere 117:151-157. https://doi.org/10.1016/j.chemosphere.2014.06.013

Goto Y, Yoshida N (2019) Scaling up microbial fuel cells for treating swine wastewater. Water 11:1803. https://doi.org/10.3390/w11091803

He L, Du P, Chen Y, Lu H, Cheng X, Chang B, Wang Z (2017) Advances in microbial fuel cells for wastewater treatment. Renew Sustain Energy Rev 71:388-403. https://doi.org/10.1016/j.rser.2016.12.069

Heidrich ES, Curtis TP, Dolfing J (2011) Determination of the internal chemical energy of wastewater. Environ Sci Technol 45:827-832. https://doi.org/10. 1021/es103058w

Ishii SI, Suzuki S, Yamanaka Y, Wu A, Nealson KH, Bretschger O (2017) Population dynamics of electrogenic microbial communities in microbial fuel cells started with three different inoculum sources. Bioelectrochemistry 117:74-82. https://doi.org/10.1016/j.bioelechem.2017.06.003

Kalathil S, Nguyen VH, Shim J-J, Khan MM, Lee J, Cho MH (2013) Enhanced performance of a microbial fuel cell using CNT/MnO2 nanocomposite as a bioanode material. J Nanosci Nanotechnol. 13:7712-7716

Kim K-Y, Yang W, Logan BE (2015) Impact of electrode configurations on retention time and domestic wastewater treatment efficiency using microbial fuel cells. Water Res 80:41-46. https://doi.org/10.1016/j. watres.2015.05.021

Kim K-Y, Yang W, Evans PJ, Logan BE (2016) Continuous treatment of high strength wastewaters using air-cathode microbial fuel cells. Bioresour Technol 221:96-101. https://doi.org/10.1016/j.biortech.2016.09.031
Lee H-S, Torres Cl, Rittmann BE (2009) Effects of substrate diffusion and anode potential on kinetic parameters for anode-respiring bacteria. Environ Sci Technol 43:7571-7577. https://doi.org/10.1021/es9015519

Li W-W, Yu H-Q, He Z (2013) Towards sustainable wastewater treatment by using microbial fuel cells-centered technologies. Energy Environ Sci 7:911-924. https://doi.org/10.1039/c3ee43106a

Li Y, Liu L, Yang F, Ren N (2015) Performance of carbon fiber cathode membrane with C-Mn-Fe-O catalyst in MBR-MFC for wastewater treatment. J Membr Sci 484:27-34. https://doi.org/10.1016/j.memsci. 2015.03.006

Li C, Lesnik KL, Fan Y, Liu H (2016) Millimeter scale electron conduction through exoelectrogenic mixed species biofilms. FEMS Microbiol Lett 363:153. https://doi.org/10.1093/femsle/fnw153

Lin H, Wu S, Miller C, Zhu J (2013) Electricity generation and nutrients removal from high-strength liquid manure by air-cathode microbial fuel cells. J Environ Sci Health Part A 1. https://doi.org/10.1080/10934 529.2015.1094342

Liu H, Logan BE (2004) Electricity generation using an air-cathode single chamber microbial fuel cell in the presence and absence of a proton exchange membrane. Environ Sci Technol 38:4040-4046. https://doi.org/ 10.1021/es0499344

Liu H, Ramnarayanan R, Logan BE (2004) Production of electricity during wastewater treatment using a single chamber microbial fuel cell. Environ Sci Technol 38:2281-2285. https://doi.org/10.1021/es034923g

Liu F, Sun L, Wan J, Tang A, Deng M, Wu R (2019) Organic matter and ammonia removal by a novel integrated process of constructed wetland and microbial fuel cells RSC. Advances 9:5384-5393. https://doi.org/10.1039/ c8ra10625h

Logan BE (2008) Microbial fuel cells. Wiley, Hoboken, NJ, USA

Logan BE, Regan JM (2006) Microbial fuel cells_challenges and applications. Environ Sci Technol 40:5172-5180. https://doi.org/10.1021/es0627592

Lovley DR (2006) Microbial energizers: fuel cells that keep on going MicrobeAmerican Society for. Microbiology 1:323-34

Lu N, Zhou S-G, Zhuang L, Zhang J-T, Ni J-R (2009) Electricity generation from starch processing wastewater using microbial fuel cell technology. Biochem Eng J 43:246-251. https://doi.org/10.1016/j.bej.2008.10.005

Malaeb L, Katuri KP, Logan BE, Maab H, Nunes SP, Saikaly PE (2013) A hybrid microbial fuel cell membrane bioreactor with a conductive ultrafiltration membrane biocathode for wastewater treatment. Environ Sci Technol 47:11821-11828. https://doi.org/10.1021/es4030113

Malvankar NS et al (2011) Tunable metallic-like conductivity in microbial nanowire networks. Nat Nanotechnol 6:573-579. https://doi.org/10.1038/ nnano.2011.119

Millo D (2015) An electrochemical strategy to measure the thickness of electroactive microbial biofilms. ChemElectroChem 2:288-291. https://doi. org/10.1002/celc.201402425

Min B, Cheng S, Logan BE (2005) Electricity generation using membrane and salt bridge microbial fuel cells. Water Res 39:1675-1686. https://doi.org/ 10.1016/j.watres.2005.02.002

Munoz-Cupa C, Hu Y, Xu C, Bassi A (2021) An overview of microbial fuel cell usage in wastewater treatment, resource recovery and energy production. Sci Total Environ 754:142429. https://doi.org/10.1016/j.scitotenv. 2020.142429

Nakamura R, Kai F, Okamoto A, Newton GJ, Hashimoto K (2009) Self-constructed electrically conductive bacterial networks. Angew Chem Int Ed 48:508-511. https://doi.org/10.1002/anie.200804750

Nevin KP et al (2008) Power output and columbic efficiencies from biofilms of Geobacter sulfurreducens comparable to mixed community microbial fuel cells. Environ Microbiol 10:2505-2514. https://doi.org/10.1111/j.14622920.2008.01675.x

$\mathrm{Ng} \mathrm{HY}$ et al (2006) Integrated anaerobic and aerobic processes for treatment of municipal wastewater. In: Water Environment Federation 3205-3216

Nosek D, Jachimowicz P, Cydzik-Kwiatkowska A (2020) Anode modification as an alternative approach to improve electricity generation in microbial fuel cells. Energies 13:6596. https://doi.org/10.3390/en13246596

Oh SE, Logan BE (2007) Voltage reversal during microbial fuel cell stack operation. J Power Sources 167:11-17. https://doi.org/10.1016/j.jpowsour.2007. 02.016

Piculell M, Welander P, Jönsson K, Welander T (2015) Evaluating the effect of biofilm thickness on nitrification in moving bed biofilm reactors. Environ Technol 37:732-743. https://doi.org/10.1080/09593330.2015.1080308 
Read ST, Dutta P, Bond PL, Keller J, Rabaey K (2010) Initial development and structure of biofilms on microbial fuel cell anodes. BMC Microbiol 10(98):1-10. https://doi.org/10.1186/1471-2180-10-98

Ren L, Ahn Y, Logan BE (2014) A two-stage microbial fuel cell and anaerobic fluidized bed membrane bioreactor (MFC-AFMBR) system for effective domestic wastewater treatment. Environ Sci Technol 48:4199-4206. https://doi.org/10.1021/es500737m

Rodrigo MA, Cañizares P, Lobato J, Paz R, Sáez C, Linares JJ (2007) Production of electricity from the treatment of urban waste water using a microbia fuel cell. J Power Sources 169:198-204. https://doi.org/10.1016/j.jpows our.2007.01.054

Santoro C, Arbizzani C, Erable B, leropoulos I (2017) Microbial fuel cells: from fundamentals to applications. A review. J Power Sources 356:225-244. https://doi.org/10.1016/j.jpowsour.2017.03.109

Sayed ET et al (2020) A carbon-cloth anode electroplated with iron nanostructure for microbial fuel cell operated with real wastewater. Sustainability 12:6538. https://doi.org/10.3390/su12166538

Sevda S, Sreekrishnan TR (2012) Effect of salt concentration and mediators in salt bridge microbial fuel cell for electricity generation from synthetic wastewater. J Environ Sci Health Part A Toxic/hazardous Substances Environ Eng 47:878-886. https://doi.org/10.1080/10934529.2012.665004

Stoll Z, Dolfing J, Xu P (2018) Minimum performance requirements for microbial fuel cells to achieve energy-neutral wastewater treatment. Water 10:243. https://doi.org/10.3390/w10030243

Strycharz S, Tender L (2012) Reply to the 'Comment on "On electrical conductivity of microbial nanowires and biofilms"' by N. S. Malvankar, M. T. Tuominen and D. R. Lovley, Energy Environ. Sci., 2012, 5, DOI: 10.1039/ c2ee02613a. Energy Environ Sci 5:6250-6255. https://doi.org/10.1039/ C2EE03056J

Su X, Tian Y, Sun Z, Lu Y, Li Z (2013) Performance of a combined system of microbial fuel cell and membrane bioreactor: wastewater treatment, sludge reduction, energy recovery and membrane fouling. Biosens Bioelectron 49:92-98. https://doi.org/10.1016/j.bios.2013.04.005

Sun D, Chen J, Huang H, Liu W, Ye Y, Cheng S (2016) The effect of biofilm thickness on electrochemical activity of Geobacter sulfurreducens. Int J Hydrogen Energy 41:16523-16528. https://doi.org/10.1016/j.jjhydene. 2016.04.163

Vicari F, D’Angelo A, Galia A, Quatrini P, Scialdone O (2016) A single-chamber membraneless microbial fuel cell exposed to air using Shewanella putrefaciens. J Electroanal Chem 783:268-273. https://doi.org/10.1016/j. jelechem.2016.11.010

Wang X, Wang G, Hao M (2015) Modeling of the bacillus subtilis bacterial biofilm growing on an agar substrate. Comput Math Methods Med 2015:581829. https://doi.org/10.1155/2015/581829

Wei J, Liang P, Huang X (2011) Recent progress in electrodes for microbial fuel cells. Bioresour Technol 102:9335-9344. https://doi.org/10.1016/j.biort ech.2011.07.019

Wen Q, Wu Y, Cao D, Zhao L, Sun Q (2009) Electricity generation and modeling of microbial fuel cell from continuous beer brewery wastewater. Bioresour Technol 100:4171-4175. https://doi.org/10.1016/j.biortech.2009.02. 058

Xu L, Zhao Y, Doherty L, Hu Y, Hao X (2016) The integrated processes for wastewater treatment based on the principle of microbial fuel cells: a review.
Crit Rev Environ Sci Technol 46:60-91. https://doi.org/10.1080/10643389. 2015.1061884

Yadav AK, Dash P, Mohanty A, Abbassi R, Mishra BK (2012) Performance assessment of innovative constructed wetland-microbial fuel cell for electricity production and dye removal. Ecol Eng 47:126-131. https://doi.org/10. 1016/j.ecoleng.2012.06.029

Ye $Y$ et al (2019) Effect of organic loading rate on the recovery of nutrients and energy in a dual-chamber microbial fuel cell. Bioresour Technol 281:367-373. https://doi.org/10.1016/j.biortech.2019.02.108

You SJ, Zhao QL, Jiang JQ, Zhang JN (2006) Treatment of domestic wastewater with simultaneous electricity generation in microbial fuel cell under continuous operation. Chem Biochem Eng Q 20:407-412

You J, Walter XA, Greenman J, Melhuish C, leropoulos I (2015) Stability and reliability of anodic biofilms under different feedstock conditions: towards microbial fuel sensors. Cell Sens Sens Bio-Sens Res 6:43-50. https://doi. org/10.1016/j.sbsr.2015.11.007

Yu J, Park Y, Widyaningsih E, Kim S, Kim Y, Lee T (2021) Microbial fuel cells: devices for real 23 wastewater treatment, rather than electricity production. Sci Total Environ 775:145904. https://doi.org/10.1016/j.scitotenv. 2021.145904

Yu J, Seon J, Park Y, Cho S, Lee T (2012) Electricity generation and microbial community in a submerged-exchangeable microbial fuel cell system for low-strength domestic wastewater treatment. Bioresour Technol 117:172-179. https://doi.org/10.1016/j.biortech.2012.04.078

Yu Y-Y, Zhai D-D, Si R-W, Sun J-Z, Liu X, Yong Y-C (2017) Three-dimensional electrodes for high-performance bioelectrochemical systems. Int J Mol Sci 18:90. https://doi.org/10.3390/ijms18010090

Yuan Y, Zhou L, Hou R, Wang Y, Zhou S (2020) Centimeter-long microbial electron transport for bioremediation applications. Trends Biotechnol 39:181-193. https://doi.org/10.1016/j.tibtech.2020.06.011

Zhang B, Zhao H, Zhou S, Shi C, Wang C, Ni J (2009) A novel UASB-MFC-BAF integrated system for high strength molasses wastewater treatment and bioelectricity generation. Bioresour Technol 100:5687-5693. https://doi. org/10.1016/j.biortech.2009.06.045

Zhang F, Ge Z, Grimaud J, Hurst J, He Z (2013) Long-term performance of literscale microbial fuel cells treating primary effluent installed in a municipal wastewater treatment facility. Environ Sci Technol 47:4941-4948. https:// doi.org/10.1021/es400631r

Zhou M, Chi M, Wang H, Jin T (2012) Anode modification by electrochemical oxidation: a new practical method to improve the performance of microbial fuel cells. Biochem Eng J 60:151-155. https://doi.org/10.1016/j. bej.2011.10.014

Zhu F, Wang W, Zhang X, Tao G (2011) Electricity generation in a membraneless microbial fuel cell with down-flow feeding onto the cathode. Bioresour Technol 102:7324-7328. https://doi.org/10.1016/j.biortech. 2011.04.062

\section{Publisher's Note}

Springer Nature remains neutral with regard to jurisdictional claims in published maps and institutional affiliations.

\section{Submit your manuscript to a SpringerOpen ${ }^{\circ}$ journal and benefit from:}

- Convenient online submission

- Rigorous peer review

- Open access: articles freely available online

- High visibility within the field

Retaining the copyright to your article

Submit your next manuscript at springeropen.com 